\title{
The threatened and near-threatened birds of Luzon, Philippines, and the role of the Sierra Madre mountains in their conservation
}

\author{
MICHAEL KØIE POULSEN
}

\begin{abstract}
Summary
Fieldwork on the distribution, status and ecology of birds was conducted in the northern Sierra Madre mountain range, Luzon, Philippines, during March-May 1991 and MarchMay 1992. The findings show the area to be one of the most important for conservation of threatened species of birds in all Asia. The results are here combined with evidence from earlier surveys by other searchers. Fourteen threatened and 18 near-threatened species are now known from the area. This paper reports on all the threatened and near-threatened resident species of the island of Luzon, with special emphasis on their occurrence in the Sierra Madre mountains. In addition, the paper treats species with very limited global distribution that breed in Luzon, and lists species of forest birds endemic to the Philippines that have not previously been reported from the Sierra Madre mountains. Maps show the known sites for 17 species of special concern for conservation. New data on the altitudinal distribution of threatened and near-threatened species suggest that it is essential to protect primary forest at all elevations.
\end{abstract}

\section{Introduction}

No other Asian island has as many threatened species of bird as Luzon, closely followed by Mindanao, both in the Philippines. A total of 42 species listed as threatened or near-threatened by Collar and Andrew (1988) are known from Luzon including 15 breeding species listed as threatened. The vast majority of species of special concern to conservation (threatened, nearthreatened and restricted-range) depend on forested habitats. Habitat destruction has been so widespread all over the Philippines that large blocks of forest capable of supporting individual populations of particular species are very few in number. Indeed, the current state of forest in the Philippines is arguably the worst in tropical Asia: the approximate original extent of closedcanopy tropical moist forest in the archipelago was $295,000 \mathrm{~km}^{2}$, but data from 1988 show that only $22 \%$ of such forest is left, including $34,128 \mathrm{~km}^{2}$ Dipterocarp residual forest, $9,883 \mathrm{~km}^{2}$ Dipterocarp old growth forest, and $11,374 \mathrm{~km}^{2}$ mossy forest (IUCN 1991).

One of the largest remaining blocks of forests in the Philippines is located in the Sierra Madre mountains in northern Luzon (see Figure 1). With the highest mountain peaks reaching 1,200 to $1,800 \mathrm{~m}$, this mountain chain extends almost 


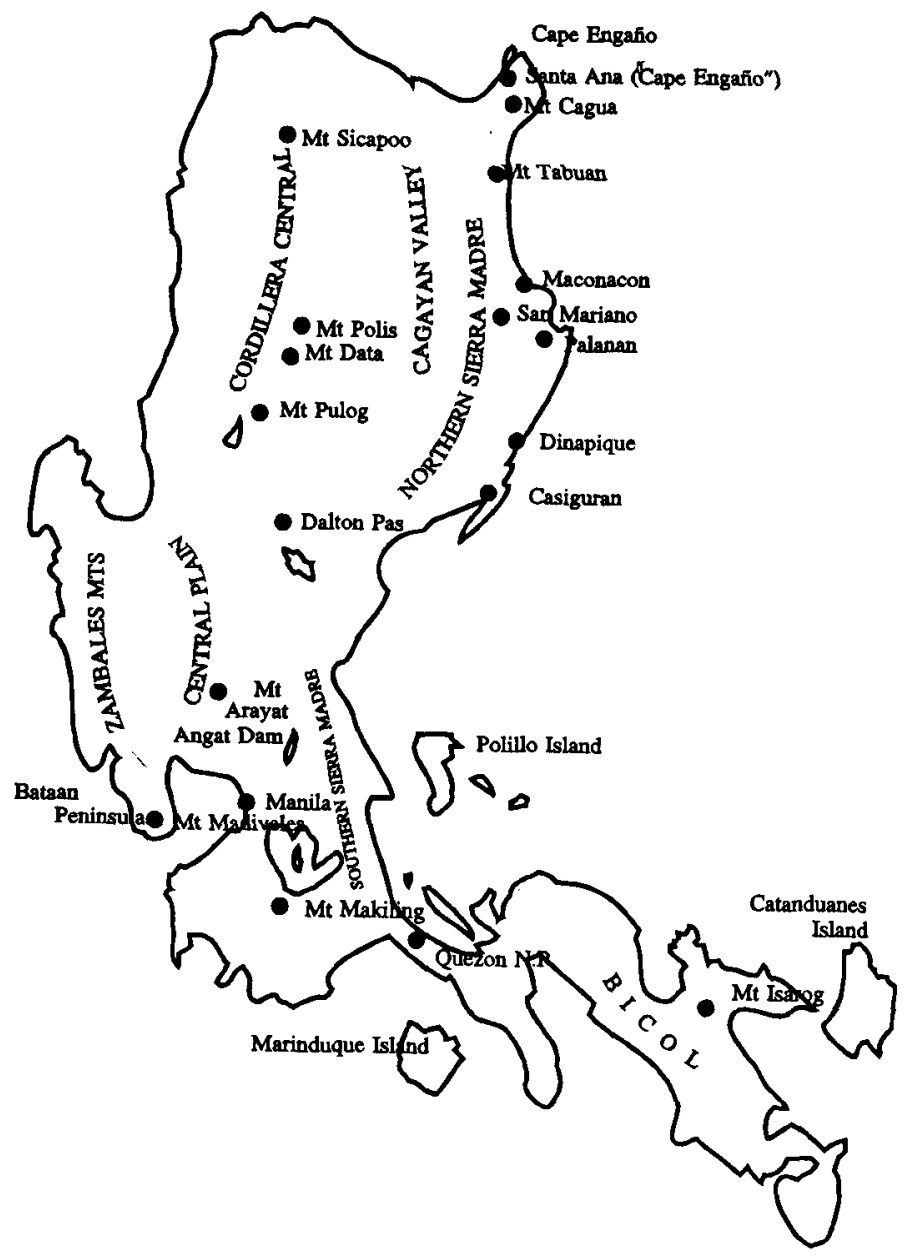

Figure 1. The island of Luzon, Philippines.

$500 \mathrm{~km}$ from the north-eastern tip of Luzon southward, forming the backbone of the island. A deep valley at around $15^{\circ} 30^{\prime} \mathrm{N}$ separates the mountains into northern and southern ranges, and until recently little research on flora and fauna had been undertaken north of this divide. Owing to this lack of information, the area was often accorded a low conservation priority and did not receive the recognition that it deserves considering the amount of habitat remaining and the number of threatened and near-threatened bird species that it might have been expected - and has now been proved - to contain.

The information on the birds of the Sierra Madre mountains presented here is based mainly on findings from joint surveys of DENR (Department of Environment and Natural Resources, the Philippines) and ICBP (International Council for Bird Preservation; now BirdLife International) in 1991 and 1992. In addition, data from the ICBP Biodiversity Project (ICBP 1992, Stattersfield et al. in prep.), from collections at the Philippine National Museum (PNM) and the University of the Philippines in Los Baños (UPLB), and from field researchers 
who have recently visited Luzon, are added. General information about distribution is mainly from Dickinson et al. (1991), which contains an almost complete presentation of previous knowledge on which species are known from which islands.

\section{Protected areas system}

Today, most of the remaining areas of lowland rainforest in the Sierra Madre mountains are under logging concessions. In 1979, President Marcos declared all forest lands within a $45 \mathrm{~km}$ radius from Palanan Point in Palanan, Isabela province, as a wilderness area (Letter of Instructions no. 917, 1979). This area comprises more than 200,000 ha. Since 1979, it has also been compulsory that companies in each concession area establish wilderness areas, covering $5 \%$ of the logged-over areas and another $5 \%$ of primary forest. In addition, all mossy forests in the concession area should have the status of wilderness area. Nevertheless, the 12 wilderness areas in the northern Sierra Madre mountains exist only on paper. The Philippine government is now embarking on a large programme to develop a comprehensive Integrated Protected Area System (IPAS) in the country. Recent resolutions (nos. 1,786 and 1,787) of the Philippine Senate give the Wilderness Area at Palanan priority for inclusion in IPAS and requests UNESCO to declare the Palanan area a World Heritage Site.

\section{Ornithological exploration of the Sierra Madre mountains}

Previously the most important ornithological work in the region was done by John Whitehead, who visited the area around Santa Ana in Cagayan province in 1895, referring to the area as "Cape Engaño". However, a close reading of Ogilvie Grant and Whitehead (1898) suggests that he only visited Pulaui, where Cape Engaño is situated, for a single day (17 May 1895) and worked around Santa Ana in Luzon from 15 April to at least 26 May 1895. The year before, he did some collecting in the Sierra Madre in Isabela province around San Mariano, which he refers to as "Molino" (Whitehead 1899).

Specimens in museum collections indicate that several other collectors have visited the northern Sierra Madre mountains: C. G. Semper visited Casiguran in Aurora province prior to ${ }_{1884}$ (Dickinson et al. 1991), a man named van der Valk was in the Cagayan Valley in February 1892 (Dickinson et al. 1991), F. S. Rivera was at Mt Cresta in Cagayan province in April 1929 (Manuel 1935), at Mt Tabuan in Cagayan province in May 1929 (Manuel 1935, 1936a), and probably at Mt Casiguran in Aurora province about this time (Manuel 1936b). D. S. Rabor and co-workers collected in Cagayan province in April-May 1960, working around Mt Cagua from 3 April to 4 May and Mt Cetaceo from to to 21 May (Rand and Rabor 1967, PNM). G. Alcasid, M. Celestino, T. Oane and J. Ramos collected around San Mariano, Isabela province, in April-May 1961 (Parkes 1970, PNM). It appears that the results of this fieldwork are widely scattered in the literature.

Some researchers have also visited the northern Sierra Madre more recently: T. H. Fisher made brief visits of 2-5 days to Maconacon, Isabela province, at least eight times in the period 1978-1983; J. Hornskov and S. Jensen went into 
the mountains behind San Mariano towards Mt Palanan, Isabela province, 2026 June 1987 ; R. S. Kennedy, H. Miranda and M. Caleda visited the area around Dinapique in Isabela and Aurora provinces in 1983; and P. C. Gonzales and co-workers collected in the Palanan area, Isabela province, in May 1991.

Some parts of the southern Sierra Madre are relatively easy of access from Manila and have been visited by many researchers over the years. The lower mountains east of Laguna de Bay have been visited rather regularly and many recent visitors have been to the Angat Dam area, Bulacan province, and to Quezon National Park, which is situated within Quezon province immediately south of the southernmost part of the Sierra Madre (see Figure 1).

Dalton Pass connects the Cordillera Central with the Sierra Madre. It is the lowest pass between Cagayan valley and the Central Plain. The people living near Dalton Pass have caught migratory birds for centuries. In general the flight is from the north from September into December and from the south from January into May. Some of the forest species caught at Dalton Pass (e.g. Red-bellied Pitta Pitta erythrogaster and Ashy Ground-thrush Zoothera cinerea) may have been migrating between the Sierra Madre and Cordillera Central in response to different rainy seasons in the two ranges. Between 1964 and 1967 more than 35,000 birds of 171 species were ringed here by Alcasid and co-workers (McClure and Leelavit 1972, McClure 1974). The catching of birds at Dalton Pass was studied in 1989-1990 by Alonzo-Pasicolan (1992).

\section{Climate and vegetation}

The Sierra Madre mountains have mildly differentiated seasons, being relatively dry from December to April and wet during the rest of the year. The annual rainfall varies from under $2,000 \mathrm{~mm}$ in the lower plain of Cagayan valley to over $4,000 \mathrm{~mm}$ in the mountainous parts. The mean annual temperature in Tuguegarao, Cagayan valley, Cagayan province, close to the northern Sierra Madre mountains, is $26.6^{\circ} \mathrm{C}$. Mean maximum temperature is $32.6^{\circ} \mathrm{C}$ and mean minimum is $22.2^{\circ} \mathrm{C}$. May is usually the warmest month and January the coldest. Relative humidity is high, at $85-89 \%$. The prevailing wind direction is southerly from May to September and northerly from October to April. The daily sunshine duration ranges from 2.7 hours in December to 8.0 hours in April (Maus and Schieferli 1989).

Lowland rainforest is found from the coastal plains up to approximately $750 \mathrm{~m}$. It is dominated by trees of the family Dipterocarpaceae, with Myrtaceae, Fagaceae, Guttiferae, Fabaceae and Meliaceae frequently found (DENR 1987). Montane rainforest is found at elevations of $750-1,000 \mathrm{~m}$ and upwards. On the highest peaks, usually from around $1,400 \mathrm{~m}$, but also on exposed summits and ridges at lower elevations, there are areas of mossy forest. On calcareous soils limestone forest occurs, comprising many endemic species of plant that are adapted to this nutrient-deficient soil (Whitmore 1984). This forest type is mainly found in the low elevations around Palanan and in patches on the western slopes of the mountains. Sharply demarcated from adjoining forest is the very stunted, low forest that grows on ultrabasic rocks: extensive areas of such forest are found between Maconacon and Palanan, and along the coastline 
between Palanan and Dinapique. At some river mouths, mangrove swamps fringe the coastline. The largest mangrove areas are found at Port Dimamalansan and Port Bicobian, south of Maconacon (Walters 1991). Beach forest is found along the coastal areas, especially between Palanan and Dinapique.

\section{Fieldwork}

The joint DENR/ICBP biodiversity surveys were conducted in the Sierra Madre mountain range in the provinces of Cagayan and Isabela from 4 March to 4 May 1991 and from 12 March to 19 May 1992. The full results of these surveys are published in Danielsen et al. (1994).

Twelve camps were established in different forest types and at different altitudes (see below). Birds were monitored through a combination of line-transect surveys, systematic mist-netting and general observations, supplemented by bio-acoustical surveys and gathering of ethno-biological data. Altitudes were measured with an altimeter.

One or two line-transect survey routes of 2,00o $\mathrm{m}$ were set close to each camp. The route followed an existing path or was cut through the forest. When a transect survey was conducted, a researcher would walk alone, with a speed of 15 minutes per $250 \mathrm{~m}$ of the route, recording all birds seen or heard. A total of 40 hours was spent on each transect, making the results easily comparable.

Mist-netting stations were composed of 15-23 nets (150-200 m). Each station was usually monitored for 3-4 consecutive days before being moved to a new location. Each captured bird was fitted with a metal ring and measured. A single drop of blood from each species was collected for later DNA studies of taxonomy and populations, the samples being preserved in the Zoological Museum, University of Copenhagen. For poorly known species, detailed descriptions of plumage and soft parts were made, and additional measurements and photos taken. Only birds that occasionally died during handling were collected. The strength of evidence for the different records is noted in the species account whenever photographs, blood samples or taperecordings were taken.

The following is a list of the 12 study sites, arranged from north to south (and mapped along with other named localities on Figure 2), where line-transect surveys and mist-netting were carried out:

(1) Mt Cetaceo, Cagayan province, $17^{\circ} 42^{\prime} \mathrm{N} 122^{\circ} \mathrm{O} 2^{\prime} \mathrm{E}$ (two transects): mossy forest and primary montane forest at 1,200-1,650 m, 7-19 May 1992;

(2) Cayapa, Cagayan province, $17^{\circ} 35^{\prime} \mathrm{N} 121^{\circ} 52^{\prime} \mathrm{E}$ : degraded forest at $150-300 \mathrm{~m}$, 25 April to 3 May 1992;

(3) Los Dos Cuernos, Isabela province, $17^{\circ} 33^{\prime} \mathrm{N} 121^{\circ} 59^{\prime} \mathrm{E}$ : mossy forest and primary montane forest at 1,000-1,250 m, 27 April to 4 May 1991;

(4) Abuan, Isabela province, $17^{\circ} 11^{\prime} \mathrm{N} 122^{\circ} 11^{\prime} \mathrm{E}$ (camp along Abuan River): selectively logged forest at 150-550 m, 26-31 March 1991;

(5) Minuma, Isabela province, $17^{\circ} 09^{\prime} \mathrm{N} 122^{\circ} 06^{\prime} \mathrm{E}$ : selectively logged forest at $350-$ 650 m, 12-21 March 1992;

(6) Dimapnat, Isabela province, $17^{\circ} 09^{\prime} \mathrm{N} 122^{\circ} 24^{\prime} \mathrm{E}$ : ultrabasic forest at $0-150 \mathrm{~m}$, 11-18 April 1992; 


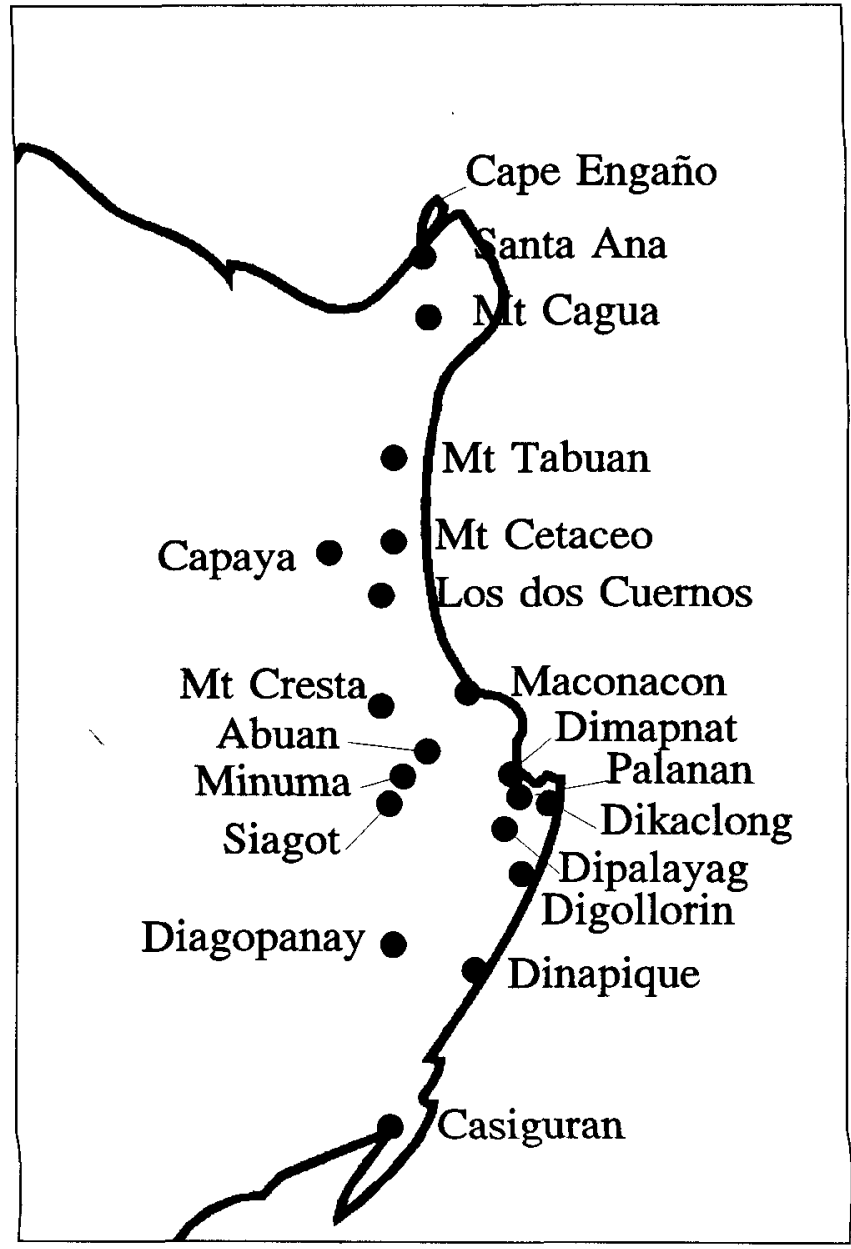

Figure 2. Sites for birds in the northern Sierra Madre mountain range, northern Luzon.

(7) Siagot, Isabela province, $17^{\circ} 06^{\prime} \mathrm{N} 122^{\circ} 04^{\prime} \mathrm{E}$ : secondary forest at $150-350 \mathrm{~m}$, 21-28 March 1992;

(8) Dikaclong, Isabela province, $17^{\circ} \mathrm{O}^{\prime} \mathrm{N} 122^{\circ} 27^{\prime} \mathrm{E}$ : selectively logged and secondary forest at $0-270 \mathrm{~m}, 11-17$ March $1991 ;$

(9) Palanan, Isabela province, $17^{\circ} 03^{\prime} \mathrm{N} 122^{\circ} 25^{\prime} \mathrm{E}$ : selectively logged and secondary forest at 0-150 m, 4-20 March 1991;

(10) Dipalayag, Isabela province, $16^{\circ} 58^{\prime} \mathrm{N} 122^{\circ} 15^{\prime} \mathrm{E}$ (two transects): primary montane and selectively logged forest at 600-1,050 m, 13-20 April 1991;

(11) Digollorin, Isabela province $16^{\circ} 50^{\prime} \mathrm{N} 122^{\circ} 26^{\prime} \mathrm{E}$ : ultrabasic forest at $0-150 \mathrm{~m}$, 4-11 April 1992;

(12) Diagopanay, Isabela province $16^{\circ} 34^{\prime} \mathrm{N} 122^{\circ} 08^{\prime} \mathrm{E}$ : primary and selectively logged forest at 400-700 m, 23-30 March 1991.

The abundance of species recorded during the surveys in 1991 and 1992 is described using the following terms: very common = recorded daily; common = 
recorded most but not all days; uncommon $=$ recorded less than every second day; rare $=$ recorded once or twice in total.

\section{Results}

A total of 14 threatened and 18 near-threatened species are now known from the Sierra Madre mountain range (classification according to Collar and Andrew 1988). Only two other threatened or near-threatened species that are presumed to breed in Luzon have not yet been found in the Sierra Madre or at Dalton Pass, namely Malayan Night-heron Gorsachius melanolophus and Philippine Cockatoo Cacatua haematuropygia. The results suggest that, apart from Whitehead's Mountain Swiftlet Collocalia whiteheadi and Red Crossbill Loxia curvirostra, all species known from the Cordillera Central in central-northern Luzon can also be found in the Sierra Madre.

Analysis of the species composition at the study sites shows that many birds only recorded at lower altitudes are either migratory visitors or widespread opportunistic species that often enter man-made habitats. The number of resident species recorded below $500 \mathrm{~m}$ was 103 , while 92 were recorded at 500$1,000 \mathrm{~m}$, and 74 at altitudes of $1,000-1,500 \mathrm{~m}$. Conservation priorities should not be based on these numbers, however, as the reduction in number of species at higher altitudes is less pronounced if only endemic forest specialists are taken into account.

The single area with the highest number of threatened species was the selectively logged forest at Minuma at $350-500 \mathrm{~m}$. Here such rare and little known birds as Whiskered Pitta Pitta kochi, Long-billed Rhabdornis Rhabdornis grandis, Rabor's Wren-babbler Napothera rabori, Blue-breasted Flycatcher Cyornis herioti and Celestial Monarch Hypothymis coelestis were all found. It is not known if these species breed within the selectively logged areas or depend on the nearby primary forest. The area originally consisted of $30-35 \mathrm{~m}$ high dipterocarp rainforest, but at the time of the DENR/ICBP survey the forest was fragmented by a web of logging roads. The forest structure was severely affected by both former and ongoing logging activities. The general canopy was under $20 \mathrm{~m}$, and the canopy cover was approximately $70 \%$, but less in the more disturbed areas. The undergrowth and understorey were very dense and impenetrable, consisting mainly of giant bamboo, rattan Calamus sp. and seedlings with some Pandanus sp.

Many species were recorded from the northern Sierra Madre for the first time, including the following forest birds endemic to the Philippines: Montane Racquet-tail Prioniturus montanus, Luzon Scops-owl Otus longicornis, Philippine Swiftlet Collocalia mearnsi, Chestnut-faced Babbler Stachyris whiteheadi, Longtailed Bush-warbler Bradypterus caudatus, White-browed Jungle-flycatcher Rhinomyias insignis, Ashy-breasted Flycatcher Muscicapa randi, Cryptic Flycatcher Ficedula crypta, Green-backed Whistler Pachycephala albiventris, Mountain Shrike Lanius validirostris, Metallic-winged Sunbird Aethopyga pulcherrima and Whitecheeked Bullfinch Pyrrhula leucogenys. Non-endemic forest birds not previously recorded were Hooded Pitta Pitta sordida, Mountain Leaf-warbler Phylloscopus trivirgatus, Mountain Tailorbird Orthotomus cuculatus, Mountain Verditer- 
flycatcher Eumyias panayensis, Mountain White-eye Zosterops montanus and Tawny-breasted Parrotfinch Erythrura hyperythra.

\section{Threatened and near-threatened bird species breeding in Luzon}

In the following accounts, one asterisk $\left(^{*}\right)$ indicates a species endemic to the Philippines and two $\left({ }^{*}\right)$ means endemic to Luzon; the sword $(t)$ indicates that the species is monotypic. Information under status and threats applies always solely to the Philippines, and is arranged in standard format. Global conservation status ( $T$, threatened; n-t, near-threatened) after each name is based on Collar and Andrew (1988) although very recently new status has been accorded by Collar et al. (1994), in some cases as a result of the present work.

Malayan Night-heron Gorsachius melanolophus (n-t)

Distribution India east to southern China and the Greater Sundas and Philippines, where the race kutteri is known from 11 islands (Dickinson et al. 1991).

Sierra Madre: not recorded, but it may occur since its habitat seems to be present.

Ecology Solitary, usually nesting singly in high forest trees, sometimes in reeds; very shy, retiring, and nocturnal (Delacour and Mayr 1946). Met with near the fish-pens of the natives, especially at dusk (McGregor 1909-1910).

Status and threats Rather rare (Delacour and Mayr 1946). An uncommon resident along forest streams (Dickinson et al. 1991). No threats are known.

\section{Philippine Eagle Pithecophaga jefferyi ${ }^{*}+(\mathrm{T})$}

Distribution Restricted to the islands of Luzon, Samar, Leyte and Mindanao (Dickinson et al. 1991), in primary forest at 0-2,000 m (Collar and Andrew 1988).

Sierra Madre: in the late 1970s the species was reported to occur in the wellforested region of Isabela, Nueva Vizcaya and Aurora provinces (Rabor 1977). Over the last two decades at least 50 supposably different birds have been recorded from the mountains (Danielsen et al. 1992). We have sight records of one at Dipalayag (1,050 m), 14 and 19 April 1991, and of two at Mt Cetaceo (1,500 m), 18 May 1992.

Ecology Depends on large areas of primary forest where it nests in large trees, hunting among the trees (Lewis 1986). It is sometimes seen soaring over the forest (Kennedy 1977). We only saw it in areas with large intact forest tracts and some selectively logged forest, and not in the lowlands.

Status and threats The entire population is estimated to be less than 200 birds (Collar and Andrew 1988). The forests of the Sierra Madre represent the largest single stronghold for the species (Lewis 1986). Three birds were reported from the Cordillera Central in the 1970s (Kennedy 1979), but all subsequent Luzon records are from the Sierra Madre. It is threatened by massive, continuing deforestation throughout its range, which makes its survival doubtful. Hunting and 
trapping increase the pressure, as indicated by at least 25 birds that are known to have been captured or shot in the Sierra Madre in the years 1970-1991 (Danielsen et al. 1992). The species appears not to use the lowlands of the Sierra Madre presumably because habitat destruction and hunting pressure is most pronounced there.

\section{Philippine Hawk-eagle Spizaetus philippinensis ${ }^{*}+(\mathrm{n}-\mathrm{t})$}

Distribution Recorded from Basilan, Luzon, Mindoro, Negros, Palawan, Siquijor, Samar, Mindanao, Leyte and Biliran.

Sierra Madre: Whitehead collected one at "Cape Engaño" in Cagayan province in 1895 and saw another on the plains that border Rio Grande in the Cagayan valley (Ogilvie Grant 1896, Whitehead 1899). Two or three birds were seen at Mt Palanan, Isabela province, in June 1987 (Hornskov 1992). The species is listed as having been caught by bird-catchers at Dalton Pass (Alonzo-Pasicolan 1992), and is also known from Quezon National Park (BirdLife database). We found it to be uncommon, with sight records at 600-1,050 $\mathrm{m}$ from Los Dos Cuernos (three individuals), between San Mariano and Dipalayag (one and two birds), and Diagopanay (one and two individuals). A bird struck by gunshot was shown to us at Disolap Nursery, east of San Mariano.

Ecology Found only in forest (McGregor 1909-1910). All our records were from areas with mid-mountain primary and selectively logged forest. Two birds at Diagopanay were displaying in the late morning of 29 March 1991, and later perched in the canopy of primary forest.

Status and threats This species is considered uncommon in lowland and midmountain forest by Dickinson et al. (1991), rare by McGregor (1909-1910) and Delacour and Mayr (1946). It seems to survives at low densities on a number of islands where large tracts of primary forest still exist. It is clearly threatened on Mindoro and Negros (Evans et al. 1992). It seems to be rare in the lowlands, probably owing to habitat destruction and hunting.

\section{Tabon Scrubfowl Megapodius cumingii $(\mathrm{n}-\mathrm{t})$}

Distribution Indonesia on islands off north and east Borneo, Sulawesi and the Sangihe and Talaud islands, and the Philippines, where the race pusillus was probably on every island of any size (McGregor 1909-1910), i.e. some 40 islands (Dickinson et al. 1991).

Sierra Madre: Whitehead collected one at "Cape Engaño" in 1895 (Ogilvie Grant 1896). Not recorded since, but we were told that people regularly collect eggs of scrubfowl in the coastal scrub east and south of Maconacon.

Ecology Coastal scrub on small islands, and montane forest (Dickinson et al. 1991). It is (or once was) frequently met with at considerable distance inland on wooded plains and hills (McGregor 1909-1910).

Status and threats Once widespread and common (Whitehead 1899, McGregor 1909-1910), now local and uncommon (Dickinson et al. 1991), this species has evidently suffered a severe decline this century and recent reports 
are few. The main threats are probably egg collection, hunting and habitat destruction. The spread of dogs and rats might be an additional problem.

Worcester's Buttonquail Turnix worcesteri ${ }^{* *}+(\mathrm{T})$

Distribution Recorded from Dalton Pass, Nueva Vizcaya province, where a series was collected in the late 1960s (Amadon and duPont 1970, Collar and Andrew 1988), and from Benguet province (Dickinson et al. 1991). A record from Parañque, Rizal province, 26 July 1934 (McGregor and Manuel 1936), is considered doubtful (Dickinson et al. 1991).

Sierra Madre: only recorded from Dalton Pass, most recently in 1989-1990 (Alonzo-Pasicolan 1992), but possibly elsewhere, since the Dalton Pass birds may have been migrating between the Sierra Madre and the Cordillera Central.

Ecology There appear to be no field observations. Possibly restricted to the grassland of higher altitudes (Collar and Andrew 1988, Dickinson et al. 1991). The doubtful record from Parañque is probably the only lowland record.

Status and threats Nothing is known of either status or threats, although the dearth of records suggests it is a rare species with strict habitat requirements.

\section{Brown-banded Rail Dryolimnas mirificus ${ }^{*}$ (T)}

Distribution Known from Dalton Pass and Imugan in Nueva Vizcaya province, Papaya in Nueva Ecija province, Liwan in Mountain province, Baguio in Benguet province, and from Camarines Norte province (Dickinson et al. 1991).

Sierra Madre: only known from birds trapped in Dalton Pass, of which there was a total of 191 in the years 1965-1970, with five birds caught in Nueva Ecija province in 1965 (McClure and Leelavit 1972). These birds may have been on migration either between Cagayan valley and the Central Plain or between the Sierra Madre and the Cordillera Central.

Ecology Nothing is known. Almost all records are from the foothills and apparently involve individuals in post-breeding dispersal (Dickinson et al. 1991).

Status and threats The species remains virtually unknown, and the lack of records away from Dalton Pass suggests that it is rare species with strict habitat requirements. Rails, snipe and other birds that can be caught in rice fields are regularly sold from roadsides: Brown-banded Rail seems not to be among them.

Flame-breasted Fruit-dove Ptilinopus marchei ${ }^{* *}+(\mathrm{n}-\mathrm{t})$

Distribution See Map 1. Known from the Cordillera Central, Sierra Madre and Mt Banahao. Erroneously mentioned from Polillo (Dickinson et al. 1991).

Sierra Madre: known from Mt Tabuan in Cagayan province (Manuel 1936b), Mt Casiguran probably near Casiguran in Aurora province (Manuel 1936b), and Dalton Pass in Nueva Vizcaya province (Alonzo-Pasicolan 1992). We have sight records from Mt Cetaceo (850-1,500 m) and Los Dos Cuernos (1,150 m), plus a report from the latter site at 1,200-1,400 $\mathrm{m}$ in May 1992 (T. H. Fisher verbally). 


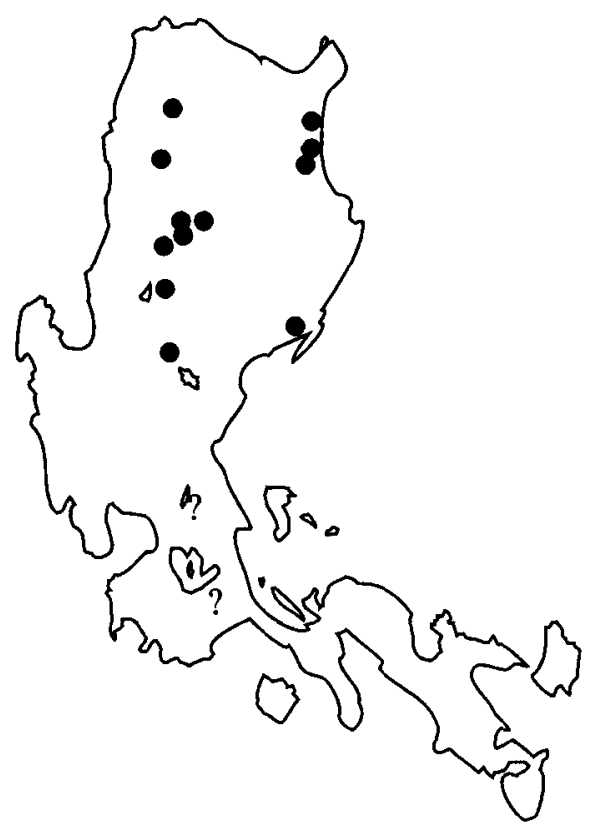

Map 1. Flame-breasted Fruit-dove Ptilinopus marchei.

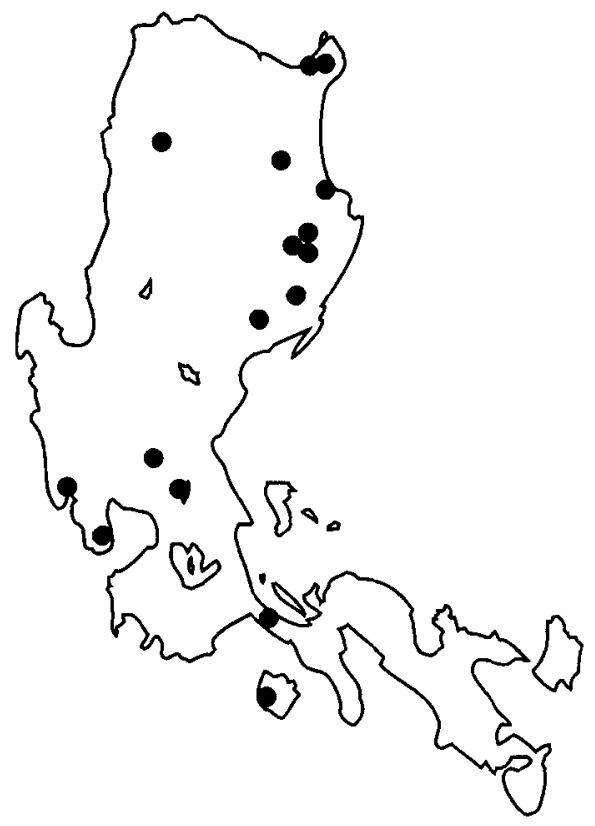

Map 3. Green Raquet-tail

Prioniturus luconensis.

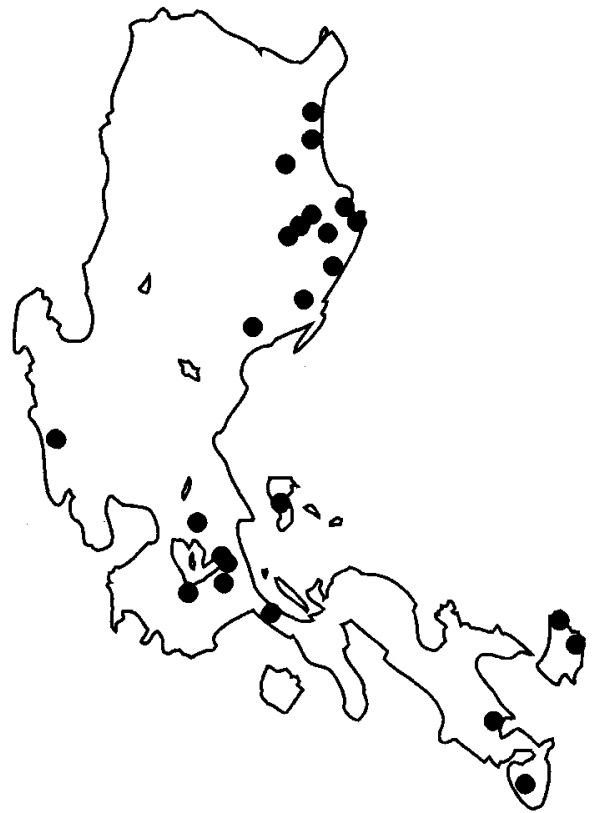

Map 2. Cream-bellied Fruit-dove Ptilinopus merrilli.

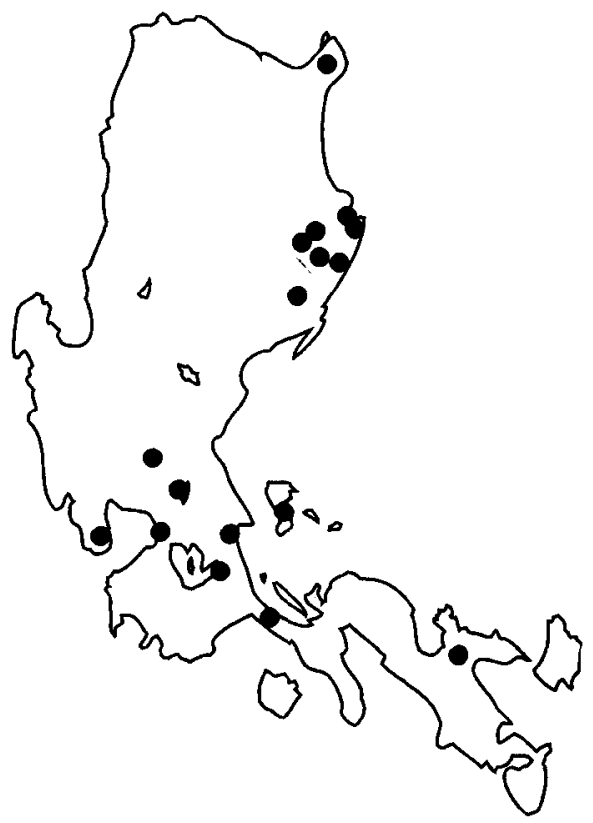

Map 4. Rufus Coucal Centropus unirufus. 
Our records, combined with comments from indigenous Agtas, suggest that it is uncommon in the Sierra Madre.

Ecology Lives among stunted trees near mountaintops (Delacour and Mayr 1946). The elevation of $300 \mathrm{~m}$ for the type-specimen is likely to be an error, as the species has never since been reported so low. We found it only above $850 \mathrm{~m}$ in primary forest, and it seems to prefer forest above 1,00o $\mathrm{m}$. Flocks of up to five birds have been reported (BirdLife database, T. H. Fisher verbally).

Status and threats Rare and local (Dickinson et al. 1991), and has probably always been so. It has not been recorded in secondary forest, seems not to survive in areas affected by selective logging, and hence might better be regarded as threatened than near-threatened. Habitat destruction and hunting would be serious factors against it.

\section{Cream-bellied Fruit-dove Ptilinopus merrilli * $(\mathrm{n}-\mathrm{t})$}

Distribution See Map 2. Confined to Luzon, Catanduanes and Polillo islands, where it is rare and local in forest up to $1,000 \mathrm{~m}$ (Dickinson et al. 1991). The race faustinoi is only known from the northern Sierra Madre.

Sierra Madre: previous records from the northern section of the mountains are from Mt Tabuan in Cagayan province (Manuel 1936a), Mt Palanan in Isabela province (Hornskov 1992), and Mt Casiguran probably near Casiguran in Aurora province (Manuel 1936b). We found it common at Los Dos Cuernos, Abuan, Dimapnat and Dipalayag, and uncommon at Mt Cetaceo, Minuma, Palanan, Digollorin and Diagopanay. The nominate race merrilli is known from near Tanay in Rizal province (Manuel 1936b), Lucban in Quezon province (Baud 1978), and several other sites east of Laguna de Bay (BirdLife database). It is regularly reported from Quezon National Park (Turton et al. 1986, Greensmith 1990, Hornskov 1992, T. H. Fisher in litt.).

Ecology We found it singly or in pairs in both primary and selectively logged forest at 0-1,100 m, except for two birds at 1,300 $\mathrm{m}$ on Mt Cetaceo which seems to be the altitudinal record for the species. This is one of the few species that was also found to be common in the surveyed ultrabasic forest. Nearly all birds were seen in the forest canopy, often foraging in fruiting trees, but two mistnetted individuals must have been flying within $2 \mathrm{~m}$ of the ground.

Status and threats Although considered to be rare and local by Dickinson et al. (1991), it appears to be rather common in the Sierra Madre. It suffers from hunting pressure, but is still able to survive in small numbers even in populated areas such as around the village of Palanan.

\section{Spotted Imperial-pigeon Ducula carola * $(\mathrm{n}-\mathrm{t})$}

Distribution Found on Luzon, Mindoro, Sibuyan, Negros, Siquijor and Mindanao (Dickinson et al. 1991). The race carola is restricted to Luzon, Mindoro and Sibuyan.

Sierra Madre: Whitehead found this species fairly common in parts of northern Luzon and collected specimens in Isabela province, presumably close to San 
Mariano, in 1894, and at "Cape Engaño", Cagayan province, in 1895 (Ogilvie Grant 1895a, 1896, Whitehead 1899). Alcasid and co-workers collected at least 11 specimens near San Mariano in April-May 1961 (specimens in PNM). The species is sometimes observed in large numbers near Angat Dam in Bulacan province (T. H. Fisher verbally), and has been caught by bird-catchers at Dalton Pass in Nueva Vizcaya province (McClure and Leelavit 1972, Alonzo-Pasicolan 1992). It is also known from Quezon National Park (Turton et al. 1986). Our only record is from Mt Cetaceo $(1,500 \mathrm{~m})$, where a flock of 10 birds was seen. Several sightings of a Ducula sp. at the same site might refer to this species.

Ecology Forest and forest edge from the lowlands to 2,000 $\mathrm{m}$ (Dickinson et al. 1991).

Status and threats Although judged uncommon (Dickinson et al. 1991) it seems to be locally fairly common at certain times. It has presumably become rare at lower altitudes due to habitat destruction and hunting.

\section{Philippine Cockatoo Cacatua haematuropygia * $+(\mathrm{T})$}

Distribution Recorded from about 40 different islands in the Philippines, but today probably restricted to a few islands (see, e.g., Lambert 1992a). From Luzon it is only known from Albay province (Ogilvie Grant ${ }_{1895} \mathrm{C}$ ) and Mt Isarog, Camarines Sur province (Goodman and Gonzales 1990).

Sierra Madre: never recorded and probably does not occur. Whitehead reported finding it throughout the Philippines except for northern Luzon, and questioned natives in Isabela province who did not know it (Whitehead 1899). It may no longer breed in Luzon.

Ecology Frequents forest, forest edge and second growth (Collar and Andrew 1988). Usually met with in small flocks in either forest or fields (McGregor 19091910). Feeds on seeds and raids cornfields (Delacour and Mayr 1946).

Status and threats Although it was relatively recently considered common throughout the archipelago (Delacour and Mayr 1946), it is now rare (Dickinson et al. 1991). Trapping is considered the main threat (Collar and Andrew 1988). It is apparently the only threatened resident species in Luzon that cannot be protected within the Sierra Madre.

\section{Green Racquet-tail Prioniturus luconensis * + (T)}

Distribution See Map 3. Restricted to Luzon and Marinduque where it is uncommon and local (Dickinson et al. 1991).

Sierra Madre: collected by Whitehead near San Mariano, Isabela province, in 1894. D. S. Rabor collected a minimum of five near Mt Cagua, Cagayan province, 3-19 April 1960 (specimens in Los Banos and PNM). Alcasid and coworkers also collected a minimum of five near San Mariano between 21 April and 19 May 1961 (specimens in PNM). At PNM there is also a specimen collected near San Pedro in Nueva Vizcaya province on 30 April 1969. There have been sightings from Maconacon in Isabela province on 9 April 1983 and at Angat Dam in Bulacan province on 6 March 1990 (both by T. H. Fisher in litt.), with 
2-7 on four days in June 1987 at Mt Palanan in Isabela province (Hornskov 1992). In 1991 we found it to be uncommon in Diagopanay, where up to seven birds were seen passing over selectively logged forest. Elsewhere it was rare: we saw two flying over Palay, west of Los Dos Cuernos (degraded forest), and a flock of six between San Mariano and Dipalayag (selectively logged forest). Surprisingly, it was not found in the lowland forest at Abuan. In 1992 we found it only at Siagot, where it was seen singly or in pairs several times, and near Cayapa, where one bird was sighted. All our records are from altitudes between 300 and $700 \mathrm{~m}$.

Ecology Restricted to primary forest according to Collar and Andrew (1988), but other authors state that it also frequents forest edge and cultivated areas (Dickinson et al. 1991) or second growth (Gonzales and Rees 1988). It usually travels in noisy groups or in pairs, and eats fruit, particularly bananas, young corn (flowers and seeds) and rice (Whitehead 1899, Delacour and Mayr 1946, Gonzales and Rees 1988). All our records are of single birds or small groups flying over primary forest or secondary growth.

Status and threats Late last century this species was common around the foot of Mt Arayat, Pampanga province, in central Luzon, and abundant when raiding the cornfields of northern Luzon (Whitehead 1899). It was common in the canopy of lowland forest in Bataan earlier in this century, and remains locally common in lowland forest at Quezon National Park (Collar and Andrew 1988), although it was judged very rare there in 1989-1990 (F. R. Lambert in litt.). Although threatened by habitat destruction, and by trapping for bird markets (Collar and Andrew 1988), it must still be regarded as relatively secure in the Sierra Madre and at Bataan, but the populations are declining and the species is now nowhere common; we did not record it close to human centres presumably owing to hunting pressure, and it has not been reported from the Cordillera Central this century. Forest loss at lower altitudes might have caused its local extinction.

\section{Rufous Coucal Centropus unirufus ${ }^{* *}+(\mathrm{n}-\mathrm{t})$}

Distribution See Map 4. Luzon and adjacent small islands.

Sierra Madre: known from Mt Cagua in Cagayan province (material in PNM), Angat Dam in Bulacan province and Quezon National Park (Hornskov 1992). We found it to be uncommon in primary and selectively logged forest at o-1,200 m, recording it at Los Dos Cuernos, Abuan, Minuma, Dimapnat, Siagot, Dikaclong, Palanan, Dipalayag, Digollorin and Diagopanay.

Ecology Found in tangled lowland forest especially where interlaced with climbing bamboo (Dickinson et al. 1991). The species is secretive and easily overlooked. We saw it singly, in pairs or small groups, often within dense vegetation in the lower forest storeys, and once following a mixed-species flock.

Status and threats Rare (Delacour and Mayr 1946); uncommon and local (Dickinson et al. 1991). This species seems able to survive in selectively logged forest, even close to human centres, so is probably not in immediate danger of extinction. 
Luzon Scops-owl Otus longicornis ${ }^{* *}+(\mathrm{n}-\mathrm{t})$

Distribution See Map 5. Luzon.

Sierra Madre: previously recorded from Ipo Dam in Bulacan province (Amadon and duPont 1970). We recorded it on Mt Cetaceo, where several birds were heard calling nightly and four birds were caught, and at Mt Dipalayag, where it was calling almost every night and one bird was caught in a mist-net.

Ecology In both rainforest and pine-forest at 350-2,200 m (Dickinson et al. 1991). We found it in montane forest at 700-1,500 m.

Status and threats Uncommon (Dickinson et al. 1991). This species was only recorded at higher altitudes. It might have become rare in the lower montane forest owing to habitat destruction. Protection of primary forest at higher altitudes is necessary to protect this species.

\section{Philippine Eagle-owl Bubo philippensis * $(\mathrm{n}-\mathrm{t})$}

Distribution Restricted to Luzon, Catanduanes, Leyte, Samar and Mindanao. The race philippensis is restricted to Luzon and Catanduanes (Dickinson et al. 1991).

Sierra Madre: one earlier sight record from Isabela province (Whitehead 1899). We saw a bird perched during the daytime in the lowest part of the canopy in selectively logged forest close to Palanan $(50 \mathrm{~m})$, and we found another, again perched during the daytime, in degraded forest at Cayapa $(200 \mathrm{~m})$. One bird was tape-recorded at night south of Maconacon, Isabela province, in degraded forest ( $350 \mathrm{~m})$.

Ecology In forest, apparently only at lower altitudes, often near rivers or lakes (Dickinson et al. 1991). Our birds, however, were not close to significant waterbodies.

Status and threats Uncommon (Dickinson et al. 1991). No threats are known, but hunting and habitat destruction might be problems.

\section{Philippine Dwarf-kingfisher Ceyx melanurus * $(\mathrm{n}-\mathrm{t})$}

Distribution Found in Luzon and adjacent islands (Polillo, Alabat, Catanduanes), Leyte, Samar, Basilan and Mindanao. The race melanurus is restricted to Luzon and adjacent islands.

Sierra Madre: previously recorded apparently from near San Mariano in Isabela province (Ogilvie Grant 1895a) and in Quezon National Park (F. R. Lambert in litt.). In May 1991 collected by Gonzales and co-workers near Palanan (material in PNM). We only recorded this species twice: both were sightings of single birds in Minuma at $350 \mathrm{~m}$.

Ecology Lives within true forest, away from water, usually perching only 1.5-3 $\mathrm{m}$ above the ground (Delacour and Mayr 1946). In primary forest (Dickinson et al. 1991). Our birds were in primary forest away from water.

Status and threats Uncommon (Dickinson et al. 1991). If dependent on lowland as well as on primary forest this bird will be threatened by habitat destruction. 


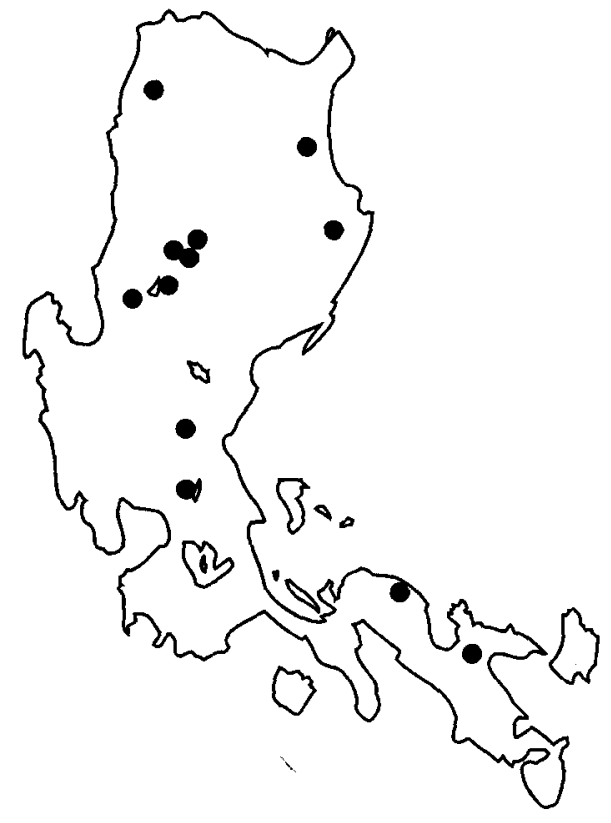

Map 5. Luzon Scops-owl Otus longicornis.

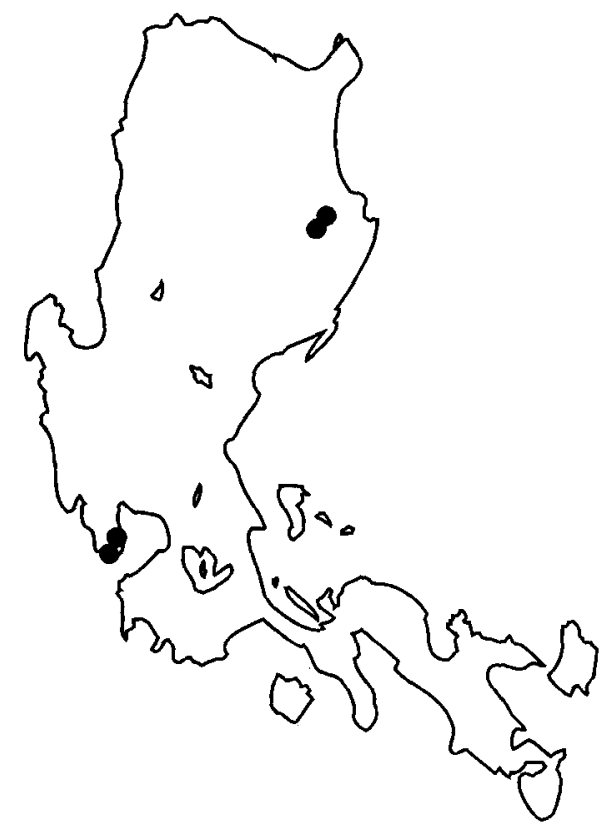

Map 7. Isabela Oriole Oriolus isabellae.

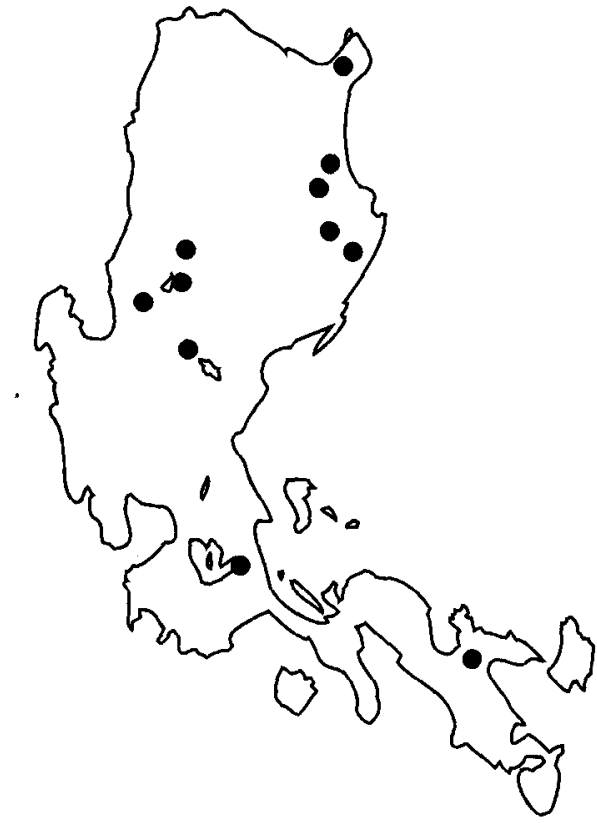

Map 6. Whiskered Pitta Pitta kochi.

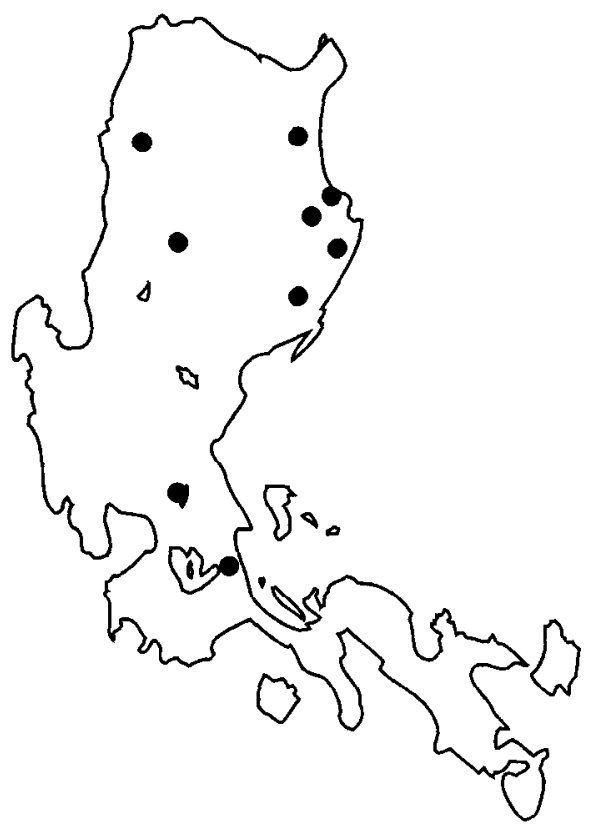

Map 8. Long-billed Rhabdornis Rhabdornis grandis. 
Spotted Wood-kingfisher Actenoides lindsayi * $(\mathrm{n}-\mathrm{t})$

Distribution Restricted to Luzon, Marinduque, Catanduanes, and Negros (Dickinson et al. 1991); also (perhaps erroneously) mentioned from Panay (Gonzales and Rees 1988). The race lindsayi is restricted to Luzon, Marinduque and Catanduanes.

Sierra Madre: no early records, but four birds were caught in Dalton Pass 19651970 (McClure and Leelavit 1972). We found it to be very common at Los Dos Cuernos, common at Mt Cetaceo and Dipalayag, and uncommon at Abuan, Palanan and Diagopanay. It frequented both primary and selectively logged forest at $0-1,450 \mathrm{~m}$. Altogether 12 birds were caught in mist-nets.

Ecology In primary and secondary forest (Dickinson et al. 1991). We found it most numerous at around 1,000-1,200 $\mathrm{m}$. Whitehead (1899), who visited the Sierra Madre when the lowland forest was less disturbed, did not record it, which suggests that it prefers mid-montane forest. Birds became more vocal and apparently more active and less shy through April and May, when presumably starting to breed. The species may therefore have been underestimated in the areas visited in March. (As this species is not caught regularly at Dalton Pass, migration is not a convincing explanation for differences in numbers of recorded birds.) We had a breeding record from primary forest at Dipalayag, where on several occasions a bird was seen leaving a hole leading horizontally into the ground on a gentle (about $20^{\circ}$ ) slope with scattered understorey.

Status and threats Fairly common (Dickinson et al. 1991). We found this species to be rare in the lowlands, possibly as a result of habitat destruction.

\section{Whiskered Pitta Pitta kochi ${ }^{* *}+(\mathrm{T})$}

Distribution See Map 6. The species was described in 1876 from a specimen known to be from Luzon and said to come from near Manila (Dickinson et al. 1991). The second record was from Mt Data in Benguet province, where Whitehead shot one and procured several other specimens snared by local hunters (Whitehead 1899). It has since been recorded once each from Mt Isarog in Camarines Sur province (Gonzales and Rees 1988), Mt Sablan in Benguet province (by D. S. Rabor in the collection at UPLB), Balian in Laguna province in 1964 (McClure and Leelavit 1972), Mt Cagua in Cagayan province (Dickinson et al. 1991), Mt Pulog National Park in Benguet province in 1989 (Jensen et al. in prep.) and Dalton Pass in 1967 (McClure and Leelavit 1972).

Sierra Madre: previous records are from Mt Cagua in the north and Balian in the far south, plus Dalton Pass (see above). At Mt Dipalayag we saw one or two adult birds several times on two successive days in primary forest $(650 \mathrm{~m})$, and we saw a single adult and netted a juvenile in montane forest at $950 \mathrm{~m}$. We caught two adult birds in mist-nets in montane oak-forest at 1,150 m on the slopes of Los Dos Cuernos, and a single adult was observed and tape-recorded at $950 \mathrm{~m}$; playback of previous tapes from the area revealed the species to be locally fairly common. During the 1992 survey one bird was seen at Minuma at $500 \mathrm{~m}$. On Mt Cetaceo $(1,200-1,650 \mathrm{~m})$ the species was common, with up to 13 birds calling in one day. A single bird has since been seen by K. Mitchell and 
N. J. Redman at just $360 \mathrm{~m}$ in degraded secondary forest on the lower slopes of Mt Halmut (Bull. Oriental Bird Club 19 [1994]: 65), and in February 1994 one bird was heard calling and seen briefly at $1,000 \mathrm{~m}$ on a ridge south-west of Adams, Ilocos Norte province, in the extreme north of the Cordillera Central (D. Allen in litt. 1994).

Ecology In montane forest on or near the ground, usually above $1,000 \mathrm{~m}$ (Dickinson et al. 1991). We found most birds in oak-dominated forest with only scattered understorey, and soft forest floor covered with leaf-litter; wild pigs occurred in similar patches, and the species seemed to prefer foraging where the soil has been rootled over by these animals. This agrees with observations from Mt Pulog in Benguet province (Jensen et al. in prep.). Once a bird was seen using the site of our campfire from some days earlier as a songpost; this was on a logging road through selectively logged forest with dense understorey. The call of Whiskered Pitta resembles that of White-eared Brown-dove Phapitreron leucotis and Philippine Coucal Centropus viridis. A dead bird we examined had been eating small beetles.

Status and threats Although described as rare and local by Dickinson et al. (1991), our work proved this species to be locally rather common at higher altitudes in the Sierra Madre. It is, however, threatened by habitat destruction and hunting. It is well known to local people at Mt Data (Whitehead 1899) and at Mt Pulog in the Cordillera Central (Jensen et al. in prep.), in both places being known as "kong kong". It is also known to local people in the Sierra Madre in Isabela and Nueva Vizcaya provinces (this survey). In these areas this and other ground-living species, especially thrushes, are hunted with snares. Our survey confirmed that the Sierra Madre are the bird's most important stronghold.

Blackish Cuckoo-shrike Coracina coerulescens ${ }^{*}(\mathrm{~T})$

Distribution Confined to Luzon, Catanduanes and Marinduque, following its extinction on Cebu (Dickinson et al. 1991). Nominate coerulescens is restricted to Luzon and Catanduanes.

Sierra Madre: collected by Rabor and co-workers near Mt Cagua in Cagayan province (PNM). Seen at Mt Palanan in Isabela province (Hornskov 1992) and near Sampaloc in Rizal province (T. H. Fisher in litt.); also known from Quezon National Park (Hornskov 1992). We found it to be common in the Sierra Madre where we recorded several hundred individuals.

Ecology In forests and secondary growth (Dickinson et al. 1991). We found it very often in mixed-species flocks, especially with other larger birds, in forested areas including secondary forest and very degraded forest at $0-1,100 \mathrm{~m}$, and although it was not recorded in ultrabasic forest in Dimapnat it occurred in other forest types in the same area. Highest density was at $300-600 \mathrm{~m}$ where 1-2.5 birds were recorded within $20 \mathrm{~m}$ of the trail for every transect kilometre.

Status and threats Uncommon and local (Dickinson et al. 1991). Common in the northern Sierra Madre. Based on its abundance in the Sierra Madre and its apparent ability to survive in secondary forest, the species does not seems to 
be threatened. However, Whitehead did not find it on his visits to the Sierra Madre in the last century, which suggests that it may have become commoner.

Isabela Oriole Oriolus isabellae ${ }^{* *}+(\mathrm{T})$

Distribution See Map 7. Confined to Luzon where only known from Bataan province and the Sierra Madre in Isabela province.

Sierra Madre: Whitehead collected one on 4 May 1894 in Isabela province, apparently near San Mariano (Ogilvie Grant 1895a). Five specimens in PNM were collected over the period 6-15 May 1961 at Barrio Disulap near San Mariano by G. Alcasid and co-workers. We were unable to relocate the species despite several visits to the Disulap area. Almost all forest in this area has been converted since 1961 .

Bataan: Single birds were collected at Mariveles in 1902 (McGregor 1903) and on the Lamao River, $5.5 \mathrm{~km}$ inland from Manila Bay near Lamao, between 14 November and 19 December 1947 (Gilliard 1950).

Ecology In the canopy of forest (especially bamboo forest) and forest edge, singly, in pairs or small groups, and in mixed-species flocks (Dickinson et al. 1991). Known from around $600 \mathrm{~m}$ according to Delacour and Mayr (1946). Gilliard (1950) provides some interesting information on the bird collected in 1947 near Lamao: it was shot from a perch $8 \mathrm{~m}$ up a tree in secondary forest on the riverbank at 50-70 m, in the company of both Black-shouldered Cuckoo-shrike Coracina morio and Blackish Cuckoo-shrike C. coerulescens. The Luzon race of Philippine Oriole Oriolus steerii albiloris, difficult to distinguish from $O$. isabellae, was also collected in the same forest during the same visit.

Status and threats While described as uncommon by Dickinson et al. (1991) there are in fact only the few records above (the last being in 1961), so the species is presumably now very rare and possibly close to extinction. Threatened by habitat destruction: virtually no forest survives in the area of the Sierra Madre from which it is known.

\section{White-fronted Tit Parus semilarvatus * $(\mathrm{n}-\mathrm{t})$}

Distribution Confined to Luzon and Mindanao. The race snowi is restricted to the northern Sierra Madre, with nominate semilarvatus recorded from the southern Sierra Madre, Bataan, Mt Arayat in Pampanga province and in Sorsogon province (Dickinson et al. 1991).

Sierra Madre: previously recorded from "Cape Engaño" in Cagayan province (Whitehead 1899), Gonzaga in Cagayan province (Dickinson et al. 1991), San Mariano in Isabela province (Ogilvie Grant 1895 C), Barrio Disulap near San Mariano (Parkes 1971), Mt Palanan in Isabela province (Hornskov 1992), Sampaloc in Rizal province (Dickinson et al. 1991) and the Angat watershed (T. H. Fisher verbally to F. R. Lambert); also known from Quezon National Park (Hornskov 1992). We found it to be rather uncommon in all types of forest $(0-1,150 \mathrm{~m})$ at Palanan, Minuma, Siagot, Cayapa and Diagopanay. Nominate semilarvatus has been seen further south in the Sierra Madre near Sampaloc, Rizal province (Dickinson et al. 1991). 
Ecology Frequents forest canopy in pairs or families (Delacour and Mayr 1946). In forest, forest edge and secondary growth below 1,000 m (Dickinson $e t$ al. 1991). We usually observed this species in the mid- and upper strata of the forest. West of Los Dos Cuernos in the lowlands between Palay and Baliuag it was found in the remaining forest pockets surrounded by open grassland, and there was even a single observation from scrub near Palay. Ten individuals, including at least two juveniles, were feeding together in degraded forest near Palay on 24 April 1991. An adult was seen feeding a juvenile in the middle of March 1991 in Minuma.

Status and threats Considered rare and local by Dickinson et al. (1991). We found it to be uncommon in the Sierra Madre. Based on its status in the Sierra Madre and its apparent ability to survive in secondary forest, the species does not seem to be threatened at present.

\section{Long-billed Rhabdornis Rhabdornis grandis ** $+(\mathrm{T})$}

\section{Distribution See Map 8. northern Luzon.}

Sierra Madre: previously recorded from Sampaloc in Rizal province (T. H. Fisher in litt.) and from the Angat watershed in Bulacan province (T. H. Fisher verbally). We saw a pair south of Maconacon in Isabela province and found the species uncommon in Diagopanay and at Dipalayag, but rather common at Los Dos Cuernos; three birds were seen at Minuma.

Ecology In middle elevation forest (Dickinson et al. 1991). We found it in primary and selectively logged forests at $350-1,250 \mathrm{~m}$, especially in areas with tall trees. It was often seen frequenting the highest parts of the canopy, singly, in pairs or up to six birds together, and in mixed-species flocks (although apparently less attached to them than Stripe-headed Rhabdornis Rhabdornis mysticalis). Two nest-holes were found at Diagopanay and Los Dos Cuernos, both 10-15 m up in dead trees. A bird was seen bringing bark-strips as nest material.

Status and threats Rare (Dickinson et al. 1991). Locally rather common in the Sierra Madre mountains. Based on the number of records from the Sierra Madre and its apparent ability to survive in secondary forest, the species does not seem to be threatened at present. However, the Sierra Madre is probably its only stronghold.

\section{Rabor's Wren-babbler Napothera rabori ${ }^{* *}(\mathrm{~T})$}

Distribution See Map 9. Nominate rabori is known from the northern Sierra Madre and Ilocos Norte province, with race mesoluzonica known from Laguna province in the southern Sierra Madre. A third subspecies is known from Mt Isarog in Camarines Sur province.

Sierra Madre: previously recorded from Mt Cagua in Cagayan province (Dickinson et al. 1991), Pakil and adjacent Pangil in Laguna province (duPont 1971, Dickinson et al. 1991) and one trapped at Maconacon, Isabela province, in 1979 (T. H. Fisher verbally), with sight-records from Angat Dam in Bulacan province in January 1990 (Gretton 1990) and Quezon National Park in March 1990 (de Roever 1990). During our survey, one adult and one juvenile were 


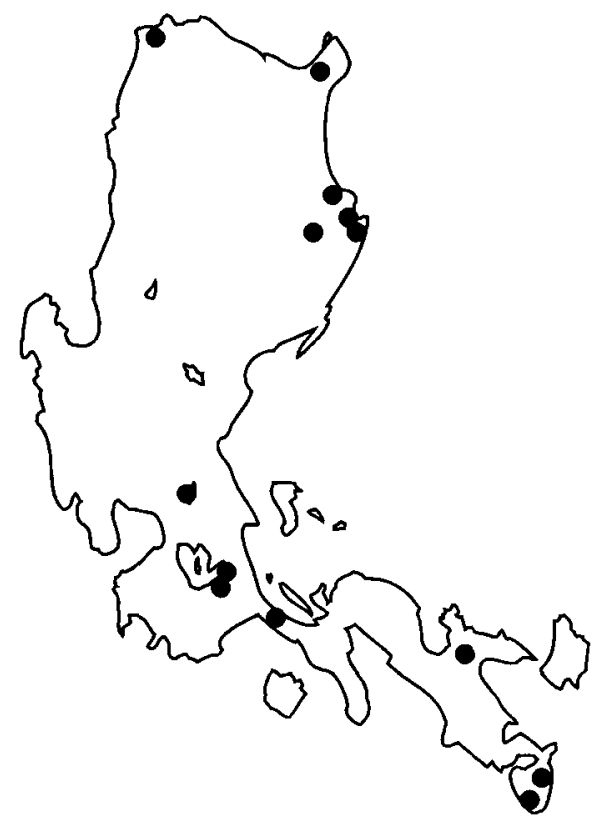

Map 9. Rabor's Wren-babbler Napothera rabori.

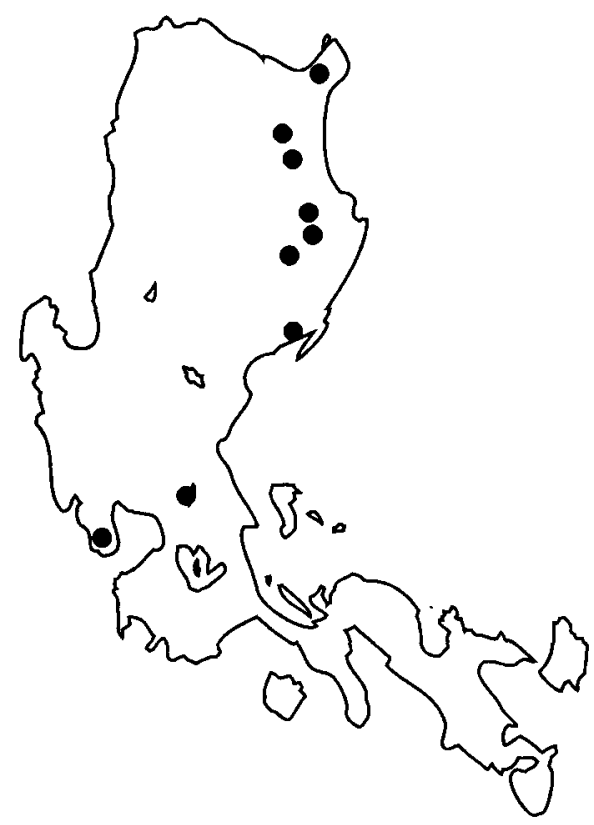

Map 11. Luzon Striped-babbler Stachyris striata.

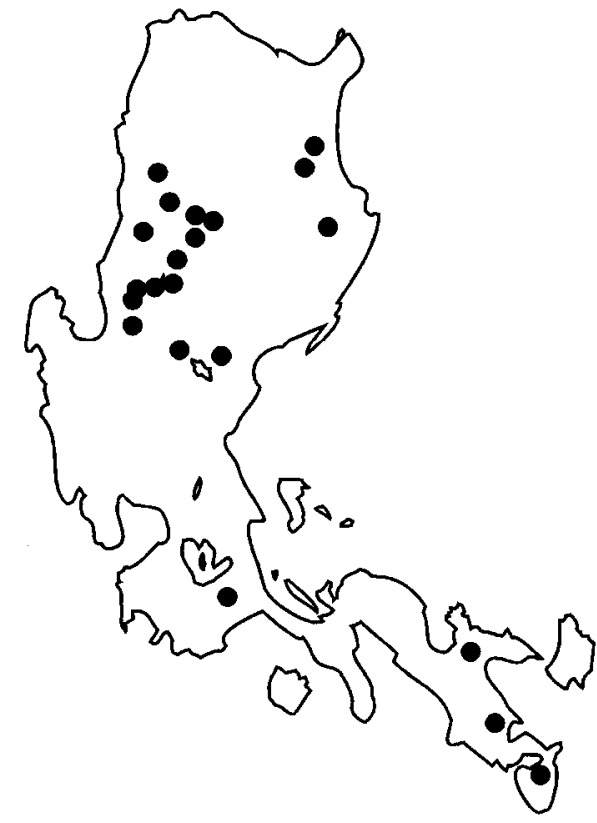

Map 10. Chestnut-faced Babbler Stachyris whiteheadi.

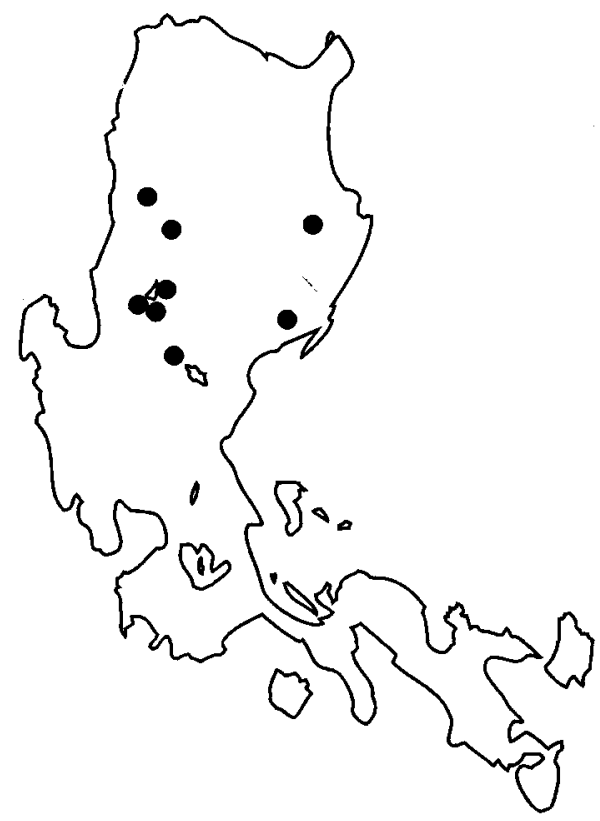

Map 12. Luzon Water-redstart Rhyacornis bicolor. 
caught, and one juvenile was sighted in Minuma. One bird, apparently juvenile, was caught by hand after it was flushed close to a small pool of water in a meadow near the edge of secondary forest $1 \mathrm{~km}$ south-east of Palanan near sea level. Also one bird was seen in Dimapnat at $350 \mathrm{~m}$.

Ecology In lowland forest and second growth up to 1,00o $\mathrm{m}$ (Dickinson et al. 1991). Seen running around on the dark, densely overgrown forest floor (de Roever 1990).

Status and threats Rare and very local (Dickinson et al. 1991). Present status is difficult to determine owing to its extremely secretive habits. Little is known about the status of this secretive species, but the limited number of reports and its demands for forest suggests that it is threatened.

\section{Chestnut-faced Babbler Stachyris whiteheadi ${ }^{* *}(\mathrm{n}-\mathrm{t})$}

Distribution See Map 10. Nominate whiteheadi is restricted to northern and central Luzon, while race sorsogonensis is restricted to the Bicol peninsula in southern Luzon.

Sierra Madre: until recently not known from the Sierra Madre, but caught at Dalton Pass (McClure and Leelavit 1972, Alonzo-Pasicolan 1992) and sighted on the western slopes in Nueva Vizcaya (Dickinson et al. 1991). We found it to be rare at Dipalayag $(1,050 \mathrm{~m})$ and Los Dos Cuernos $(1,200 \mathrm{~m})$, but abundant above $1,400 \mathrm{~m}$ at Mt Cetaceo.

Ecology Frequents thick tangles of high grass and small trees on mountainsides, as well as low shrubs in forest (Delacour and Mayr 1946). We found it the most numerous species in mossy forest at Mt Cetaceo, but failed to locate it below 1,00o $\mathrm{m}$ in the Sierra Madre. The lowest altitudes where this species has been recorded at Mt Pulog are 1,450 m (Jensen et al. in prep.) and at Mt Isarog $900 \mathrm{~m}$ (Goodman and Gonzales 1990). Dickinson et al. (1991) note that it is sometimes found in lowland forest down to $100 \mathrm{~m}$; this is apparently very unusual.

Status and threats Common in forest, second growth and scrub, usually above $800 \mathrm{~m}$ (Dickinson et al. 1991). Based on surveys at Mt Isarog in Camarines Sur province (Goodman and Gonzales 1990), Mt Pulog in Ifugao, Benguet and Nueva Vizcaya provinces (Jensen et al. in prep.), Mt Polis in Ifugao province (F. R. Lambert in litt.), hills around Banaue in Mountain province (F. R. Lambert in litt.) and Mt Cetaceo in Cagayan province (this survey), the species must be judged abundant in mossy forests on Luzon. Owing to this abundance and its ability to survive in secondary growth and scrub, it does not seem be threatened or near-threatened at present.

\section{Luzon Striped-babbler Stachyris striata ${ }^{* *}+(\mathrm{n}-\mathrm{t})$}

Distribution See Map 11. Confined to northern Luzon where it is local in forest, forest edge and secondary growth. The only records from outside the Sierra Madre are from Bataan province.

Sierra Madre: previous records are from "Cape Engaño" (Whitehead 1899) and Quibal (Dickinson et al. 1991), both in Cagayan province, around San Mariano 
in Isabela province (Whitehead 1899, Parkes 1971, specimens in PNM), Dilalugan in Aurora province, and Angat Dam ( $400 \mathrm{~m}$ ) in Bulacan province (T. H. Fisher verbally). We found it to be fairly common at Minuma (350-500 $\mathrm{m}$ ) and Siagot (150-200 m), and sighted two individuals in degraded forest at Los Dos Cuernos at $850 \mathrm{~m}$.

Ecology In the understorey of forest, including bamboo forest, forest edge and secondary growth below $500 \mathrm{~m}$ (Dickinson et al. 1991). Often forages singly or in pairs in the middle and upper levels of the forest (Gonzales and Kennedy 1990). Records from Mt Mariveles in Bataan province are from 800 to 1,000 m (T. H. Fisher verbally). Delacour and Mayr (1946) are perhaps in error in asserting that it lives at around 1,200-1,800 $\mathrm{m}$. We found it mainly in the forest understorey, but on 3 May 1991 in an overgrown forest clearing two birds were feeding silently on small berries in the foliage 3-10 $\mathrm{m}$ above the ground; they disappeared several times for periods of $5-8$ minutes, possibly to feed nestlings.

Status and threats Rare and local (Dickinson et al. 1991). The species must be considered threatened as long as it is not properly protected within the Sierra Madre.

\section{Luzon Water-redstart Rhyacornis bicolor ${ }^{* *}+(\mathrm{T})$}

Distribution See Map 12. Confined to northern Luzon south to Dalton Pass (Dickinson et al. 1991).

Sierra Madre: sighted in Nueva Vizcaya province (Dickinson et al. 1991, H. Miranda verbally) and near San Mariano in Isabela province (Hornskov 1992). Also known from Dalton Pass (Dickinson et al. 1991). We did not record this species.

Ecology Found on rocky banks along fast-flowing mountain streams within tropical montane forest or pine-forest, where it feeds on aquatic insects caught from the edge of streams or flies up to $1 \mathrm{~m}$ in the air to catch insects (Andersen et al. 1992).

Status and threats Uncommon along clear, undisturbed mountain streams and rivers above $300 \mathrm{~m}$ (Dickinson et al. 1991). Recent increases in the pollution and siltation of streams and rivers wrought by mining and logging activities threaten the survival of this species (Dickinson et al. 1991). The increased use of fertilizers, herbicides and pesticides by farmers may in some areas pollute streams and diminish its food supply (Andersen et al. 1992). The hunting for sport mentioned by Collar and Andrew (1988) is probably not a serious threat to this species.

\section{Ashy Ground-thrush Zoothera cinerea * $(\mathrm{n}-\mathrm{t})$}

Distribution Confined to Luzon and Mindoro.

Sierra Madre: recorded at Mt Palanan in Isabela province (Hornskov 1992). A total of 130 were ringed at Dalton Pass, 1964-1970 (McClure and Leelavit 1972). Other earlier records are only from the south of the Sierra Madre where it is known from Angat Dam in Bulacan province and Quezon National Park (Amadon and duPont 1970, Hornskov 1992, F. R. Lambert in litt.). We saw one 
adult bird near Diagopanay (500 $\mathrm{m}$ ) and mist-netted one and saw two adult birds at Mt Dipalayag $(1,100 \mathrm{~m})$. Two juveniles were sighted at 1,100 $\mathrm{m}$ at Los Dos Cuernos.

Ecology We found this species on and near the ground in selectively logged and primary forests at $400-1,100 \mathrm{~m}$. It seems to be very secretive. The high number of birds ringed at Dalton Pass suggests a post-breeding dispersal (Dickinson et al. 1991), but the birds might migrate between the Sierra Madre and the Cordillera Central in response to differences in the rainy season. The species has been recorded in forest with jagged limestone outcrops in Quezon National Park (F. R. Lambert in litt.).

Status and threats Uncommon in forest on or near the ground (Dickinson et al. 1991). Little is known about the status and habitat demands of this species, but it might be threatened due to deforestation. Ground-dwelling thrushes are easily caught in the snares used by local people, so hunting might be an additional threat.

\section{Long-tailed Bush-warbler Bradypterus caudatus * $(\mathrm{n}-\mathrm{t})$}

Distribution Confined to the Cordillera Central in Luzon and four mountains in Mindanao (Dickinson et al. 1991). Now also known from the Sierra Madre. Nominate caudatus is restricted to Luzon.

Sierra Madre: we saw or heard (tape-recorded) 7-10 different individuals on Mt Cetaceo $(1,400-1,650 \mathrm{~m})$. These were the first records from the Sierra Madre, and the birds here possibly represent an undescribed subspecies, as three subspecies are known from different mountain areas of Mindanao.

Ecology A secretive bird in montane forest, forest edge and dense second growth above $700 \mathrm{~m}$, singly or in pairs, on or near the ground (Dickinson et al. 1991). Lives mouse-like on the ground in mossy forest, usually above $1,800 \mathrm{~m}$ (Delacour and Mayr 1946). Our evidence certainly suggests that the species becomes commoner with increasing altitude.

Status and threats Uncommon (Dickinson et al. 1991). The species has a very small range and was probably never numerous. However, no immediate threats are known.

\section{White-browed Jungle-flycatcher Rhinomyias insignis ${ }^{* *}+(\mathrm{n}-\mathrm{t})$}

Distribution See Map 13. Confined to the Cordillera Central and the Sierra Madre in northern Luzon. Known from Mt Puguis in Mountain province (Morioka and Sakane 1979), Mt Polis in Ifugao province (Gibbs 1984), Mt Data in Benguet province (Ogilvie Grant $1895 \mathrm{~b}$ ), Pauai in Benguet province $10 \mathrm{~km}$ west of Mt Pulog (McGregor 1910) and Mt Pulog in Nueva Vizcaya province (Jensen et al. in prep.). Now also sighted in the Sierra Madre.

Sierra Madre: the only record is one bird we saw at Los Dos Cuernos (950 m) near a stream in dense primary forest with little understorey.

Ecology A secretive bird of the forest understorey of mid-mountain forest and mossy forest. Our record and records from Mt Pulog are all from the midmountain mossy forest ecotone, and the species might be restricted to a narrow 


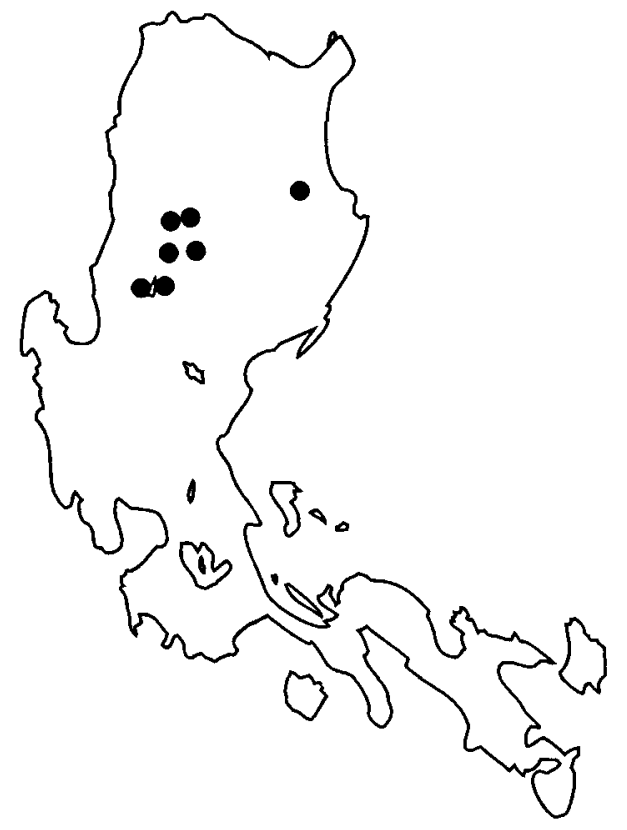

Map 13. White-browed Jungle-flycatcher Rhinomyias insignis.

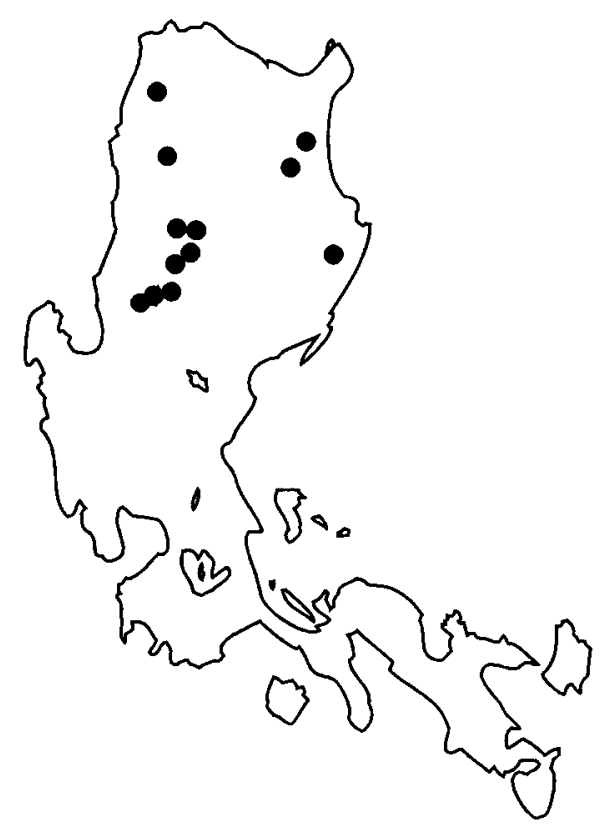

Map 15. Montane Raquet-tail Prioniturus montanus.

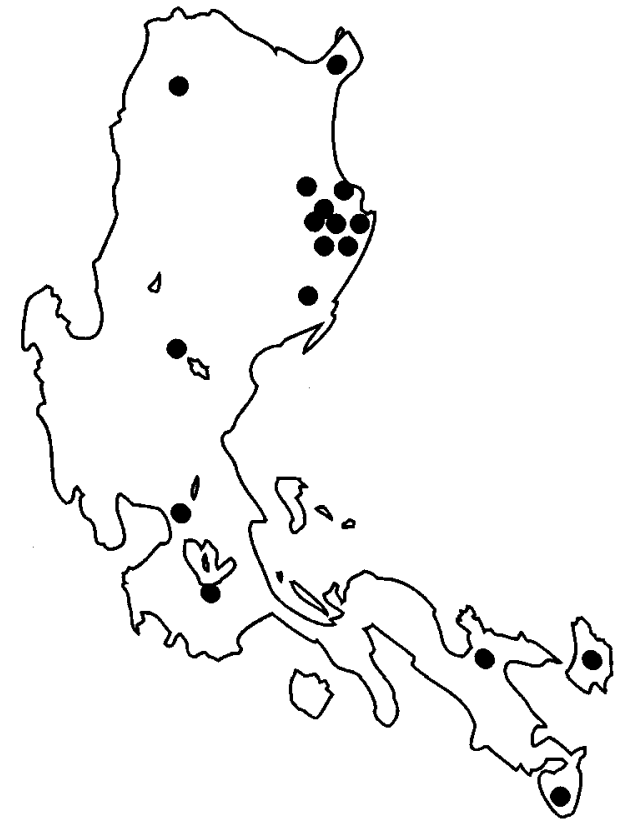

Map 14. Blue-breasted Flycatcher Cyornis herioti.

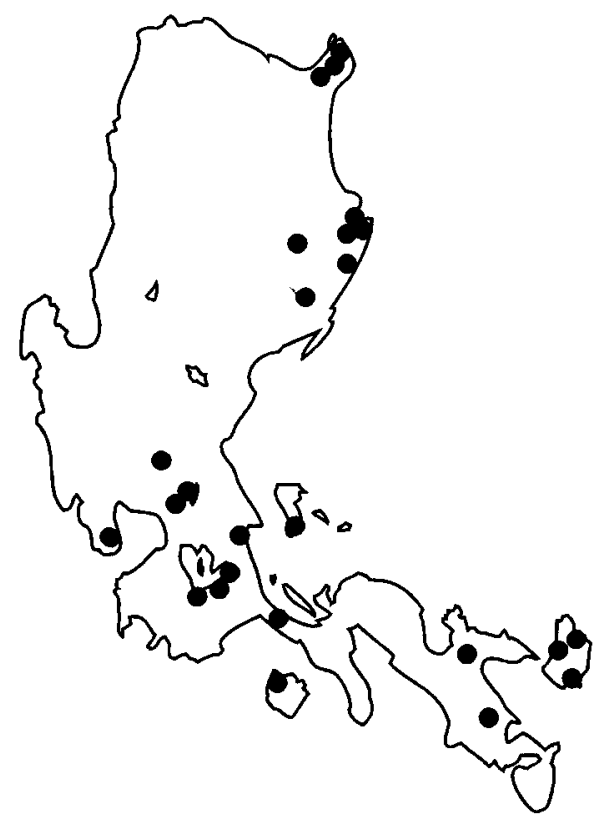

Map 16. Red-crested Malkoha

Phaenicophaeus superciliosus. 
altitudinal zone. It probably depends on primary forest, although at Mt Pulog two birds were mist-netted in second-growth bushland approximately $100 \mathrm{~m}$ away from primary forest (Jensen et al. in prep.).

Status and threats Rare and local in mossy forest above 1,000 m (Dickinson et al. 1991). The species has probably never been numerous. It might be threatened due to deforestation.

\section{Cryptic Flycatcher Ficedula crypta ${ }^{*}(\mathrm{n}-\mathrm{t})$}

Distribution Known from four mountains in Mindanao, where it is rare, and (in the race disposita) by two specimens from the Zambales Mountains of Luzon (Ripley and Marshall 1967, R. S. Kennedy in litt. 1992).

Sierra Madre: we caught four birds in mist-nets at 250-350 m, three in Minuma and one in Siagot. These birds might be disposita, but the tail in particular seemed to differ slightly from the description in Ripley and Marshall (1967) of a female from Zambales, although close to that illustrated by Dutson (1993), who saw two males on 12 July 1991 at Angat Dam.

Ecology In forest understorey and second growth, up to $10 \mathrm{~m}$ from the ground (Dickinson et al. 1991). Secretive and skulking (Ripley and Marshall 1967). We found it in selectively logged and degraded forest. Dutson (1993) describes the habitat for the birds he saw as highly degraded secondary forest with much bamboo, about $100 \mathrm{~m}$ from primary forest.

Status and threats Rare in mossy forest or mid-mountain forest below $1,500 \mathrm{~m}$ (Dickinson et al. 1991). Might be threatened due to the rapid deforestation in its very limited range.

Blue-breasted Flycatcher Cyornis herioti * $(\mathrm{T})$

Distribution See Map 14. Confined to Luzon and Catanduanes. Nominate herioti is restricted to northern and cental Luzon, while the race camarinensis is restricted to Bicol and Catanduanes.

Sierra Madre: previous records are from "Cape Engaño" and Mt Cagua (Whitehead 1899, specimens in PNM) and from Mt Cresta (Manuel 1935), all in Cagayan province, and at Mt Palanan in Isabela province (Hornskov 1992). Also caught at Dalton Pass (McClure and Leelavit 1972). We found it common at Dipalayag, uncommon in Diagopanay, Abuan and at Los Dos Cuernos, in Minuma and Dimapnat. Found in primary and selectively logged forests at 100$1,200 \mathrm{~m}$. We caught a total of 16 birds in mist-nets.

Ecology In the understorey of forests (Dickinson et al. 1991). We observed this species $1-8 \mathrm{~m}$ (average $2 \mathrm{~m}$ ) above the ground, most frequently in forest with generally closed-canopy cover in areas with a dense understorey of saplings, rattan, pandanus, bamboo, ferns and creepers. It was also present in primary forest with less understorey. A female was observed carrying food for nestlings at Dipalayag in April. It is a secretive species of the understorey and easily overlooked; although apparently not a follower of mixed flocks, it showed increased activity when such a flock passed through its territory. 
Status and threats Uncommon in lowland and middle elevation forests (Dickinson et al. 1991). We found it to be locally common in the northern Sierra Madre, but rare in the lowlands. The rarity in the lowlands may have been due to habitat destruction.

\section{Celestial Monarch Hypothymis coelestis * $(\mathrm{T})$}

Distribution Confined to Luzon, Basilan, Dinagat, Samar, Negros, Sibuyan and Mindanao. The race coelestis is restricted to Luzon, Basilan, Dinagat and Samar.

Sierra Madre: until it was discovered by F. R. Lambert (in litt.) in January 1990 near Angat Dam in Bulacan province, the only records from Luzon were from Bataan. Although not found during the 1991 survey it proved to be common at Cayapa $(175-300 \mathrm{~m})$ in 1992 (tape-recorded), and two birds were seen at Minuma at $450 \mathrm{~m}$. Known by indigenous Agtas in the Diagopanay region and reported by them to be a rare and declining resident of the primary forest.

Ecology In forest, forest edge and second growth below 1,000 $\mathrm{m}$, usually in, but not restricted to, the upper storey (Dickinson et al. 1991). Mainly in lowaltitude forests; at times associates with other birds in mixed flocks (Rand 1970).

Status and threats A rare bird with only few records in the last decade (Collar and Andrew 1988). Nowhere common (Rand 1970). The species seems to be restricted to the lowlands, where it is rare and local. It is threatened owing to the destruction of its lowland habitat.

\section{Short-crested Monarch Hypothymis helenae * (T)}

Distribution Confined to Luzon, Camiguin Norte, Polillo Island, Samar, Dinagat and north-east Mindanao. The race helenae is restricted to Luzon, Polillo and Samar.

Sierra Madre: collected near Mt Cagua in Cagayan province (Rand 1970, specimens in PNM). We found it to be common in ultrabasic forest $(0-150 \mathrm{~m})$ at Digollorin and especially at Dimapnat, and uncommon in selectively logged and primary forest $(50-550 \mathrm{~m})$ around Palanan, Abuan and Diagopanay. The species was one of the commonest during transects in Dimapnat, where up to nine birds could be counted on a single transect of $2 \mathrm{~km}$.

Ecology Understorey of forests (Dickinson et al. 1991). Found in the lower storey of low-altitude primary forest in Samar (Rand 1970). However, we also often saw it in the upper storeys, in selectively logged as well as in primary forests at $0-700 \mathrm{~m}$; it occurred singly, in pairs or in mixed-species flocks. It was one of the few species that we found more numerous in ultrabasic forest than in other forest types. On Camiguin Norte Island, where it is the only member of the genus present, its habits are those of Black-naped Monarch H. azurae (Rand 1970).

Status and threats Rare in forests (Dickinson et al. 1991). This has been considered one of the rare flycatchers of the Philippines, with occurrence limited to a few widely scattered sites, but it is abundant on Camiguin Norte Island and is evidently at least locally common in northern Luzon (Rand 1970). Deforestation 
is probably a threat, but the bird still seems to be relatively secure within the Sierra Madre.

\section{Rufous Paradise-flycatcher Terpsiphone cinnamomeus * $(\mathrm{n}-\mathrm{t})$}

Distribution Known from many Philippine islands and from Talaut Islands, Indonesia (Dickinson et al. 1991). The subspecies unirufa is restricted to Luzon and twelve other Philippine islands.

Sierra Madre: common in the forest at "Cape Engaño" in Cagayan province (Whitehead 1899). Fairly common in 1990 near Angat Dam in Bulacan province (Hornskov 1992, F. R. Lambert in litt.). Also known from Quezon National Park (Baud 1978). We found it to be scarce to uncommon at $0-475 \mathrm{~m}$, only recording a total of 11 birds, at Palanan, Abuan, Minuma and Digollorin. It is known by indigenous Agtas from the forest at Dinapique.

Ecology Found only in dense forest (Whitehead 1899). In the understorey of forests and second growth, up to $15 \mathrm{~m}$ from the ground; singly, in pairs or in mixed-species flocks; below 1,200 $\mathrm{m}$ (Dickinson et al. 1991). We found it in the understorey and the lowest part of the canopy of primary forests, selectively logged forests and second growth at $0-300 \mathrm{~m}$, where a single bird or a pair always followed mixed flocks. Rather secretive and elusive, often sitting quietly when the other species in the flock were constantly on the move.

Status and threats Uncommon (Dickinson et al. 1991). Whitehead (1899), who collected at many places within its range, found it generally scarce, but common in forest at "Cape Engaño". It is apparently a low-density species, and could be threatened by rapid deforestation in the lowlands.

\section{Green-faced Parrotfinch Erythrura viridifacies * $+(\mathrm{T})$}

\section{Distribution Confined to Luzon and Negros.}

Sierra Madre: two birds have been collected at Mt Cetaceo in Cagayan province (Dickinson et al. 1991). Alcasid and co-workers collected a minimum of 31 near San Mariano in Isabela province in May 1961 (specimens in PNM). We failed to relocate the species in either area. Four other specimens in PNM were collected by $R$. Sison at Dalton Pass in Nueva Vizcaya province. This species has also been caught by bird-trappers at Dalton Pass (Alonzo-Pasicolan 1992).

Ecology In forest, especially in bamboo, probably above 1,000 $\mathrm{m}$, although it apparently occasionally irrupts into the lowlands (Dickinson et al. 1991).

Status and threats Only a few records exist, but when found the species can evidently sometimes be rather common after the manner of bamboo specialists: the 31 specimens in PNM from near San Mariano were taken in the period 1619 May 1961. Considered uncommon by Dickinson et al. (1991). No threat is known.

\section{Restricted-range species not threatened or near-threatened}

In the ICBP Biodiversity Project bird species with a total global breeding range estimated to be below $50,000 \mathrm{~km}^{2}$ were mapped in order to locate priority areas 
for the conservation of global biodiversity (for details and rationale see ICBP 1992). Bird species with such a restricted range are clearly of special conservation value, and below I provide brief status notes on those restricted-range species which breed in Luzon (including those not covered by our fieldwork) but which were not considered threatened in Collar and Andrew (1988).

Spotted Buttonquail Turnix ocellata Previously regarded as confined to Luzon but recently also recorded from Negros (Dickinson et al. 1991). Uncommon in grasslands with occasional bushes, up to at least 1,800 m (Dickinson et al. 1991). We found it uncommon in degraded forest at Siagot and Capaya at 150-300 m.

Luzon Bleeding-heart Gallicolumba luzonica Confined to Luzon, where three subspecies are known. Uncommon in primary and secondary forest (Dickinson et al. 1991). We found it common at Digollorin, but uncommon at Palanan, Dipalayag, Los Dos Cuernos, Minuma, Siagot and in montane forest at Mt Cetaceo. It was recorded at $0-1,400 \mathrm{~m}$ in all forest types except mossy forest. It might in the near future become threatened by habitat destruction and hunting.

Montane Racquet-tail Prioniturus montanus Nominate montanus, sometimes considered a separate species, is confined to Luzon (see Map 15). Here it was previously only known from the Cordillera Central, where it is a fairly common local forest resident usually above 1,000 m (Dickinson et al. 1991). We found it to be common in the Sierra Madre in primary forest from $700 \mathrm{~m}$ upwards (Dipalayag, Los Dos Cuernos and Mt Cetaceo). It tended to perch inside the canopy, but was often seen flying in pairs or small noisy groups, often over long distances above the forested slopes (in contrast to Green Racquet-tail $P$. luconensis, it tended to avoid crossing non-forested areas). The species appears to replace $P$. luconensis at higher elevations in the Sierra Madre, although the two species have been observed in the same cornfields in Abra province (Whitehead 1899). P. montanus might in the near future become threatened by habitat destruction, hunting and trapping for bird markets.

Red-crested Malkoha Phaenicophaeus superciliosus Confined to Luzon and adjacent small islands (see Map 16). Fairly common in forests, sometimes grassland with bushes (Dickinson et al. 1991). Not recorded from the Cordillera Central. The race cagayanensis is only known from the northern Sierra Madre. We found it fairly common in primary forest, but more numerous in selectively logged forest at Palanan, Minuma, Siagot and Cayapa. In the ultrabasic forest north and south of Palanan the species was noted less frequently, with a few sightings at both Digollorin and Dimapnat; we also recorded it east of San Mariano and at Dikaclong and Diagopanay. We found it at $0-750 \mathrm{~m}$, frequenting all forest stratas, $1-3$ birds often accompanying mixed flocks especially of larger species such as Scale-feathered Malkoha Phaenicophaeus cumingi, Sooty Woodpecker Mulleripicus funebris, Greater Flameback Chrysocolaptes lucidus, Blackish Cuckooshrike Coracina coerulescens, Black-and-white Triller Lalage melanoleuca, Philippine Bulbul Hypsipetes philippinus, Balicassiao Dicrurus balicassius, Philippine Oriole Oriolus steerii and Slender-billed Crow Corvus enca. It does not seem to be threatened at present. 


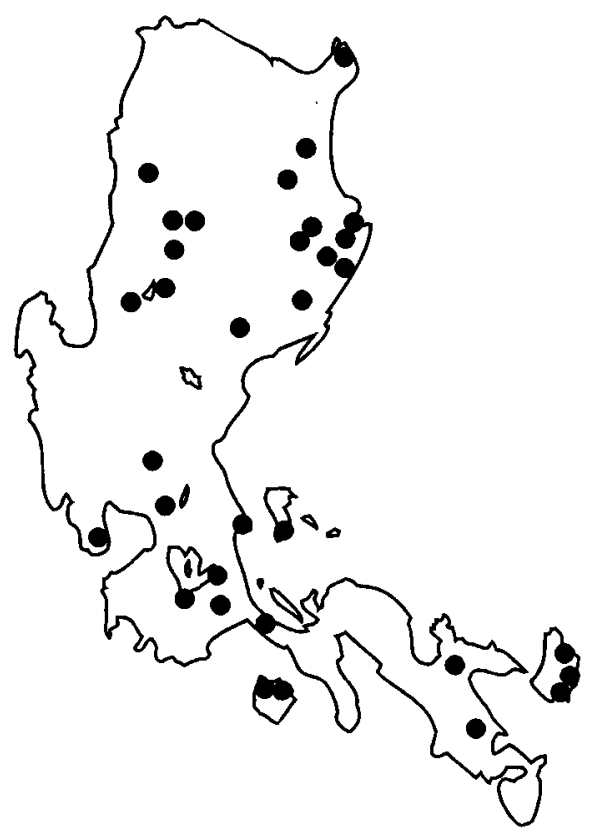

Map 17. Scale-feathered Malkoha Phaenicophaeus cumingi.

Scale-feathered Malkoha Phaenicophaeus cumingi Confined to Luzon and adjacent small islands (see Map 17), where it is fairly common up to 2,000 m (Dickinson et al. 1991). We found it common to very common in the Sierra Madre in all types of forest at $0-1,650 \mathrm{~m}$, often in mixed-species flocks. It was least common in ultrabasic forest at Digollorin and Dimapnat. It does not seem to be threatened at present.

Whitehead's Mountain Swiftlet Collocalia whiteheadi Only known from Mt Data in Luzon (nominate whiteheadi) and Mt Apo in Mindanao (race origensis) (Dickinson 1989). As a result of taxonomic confusion and the difficulty in identifying Collocalia swiftlets this species has often mistakenly been reported from other areas. It is not known from the Sierra Madre.

Indigo-banded Kingfisher Ceyx cyanopectus Confined to Luzon, Marinduque, Masbate, Mindoro, Sibuyan, Ticao, Polillo, Catanduanes, Cebu, Negros and Panay, being uncommon and local along clear forest streams below 1,000 $\mathrm{m}$ (Dickinson et al. 1991). Also near streams in deforested areas (Jensen et al. in prep). We found it in the Sierra Madre near rivers and streams in virgin and selectively logged forests (0-700 m) at Palanan, Abuan, east of San Mariano, Diagopanay, near Dimapnat, Cayapa and on the lower slopes of Mt Cetaceo. While the species may be locally rather common on Luzon, all records from Mindoro, Cebu, Ticao, Sibuyan, Negros and Panay seem to be from before 1910, suggesting that it should be considered near-threatened.

Luzon Hornbill Penelopides manilloe Confined to Luzon, Marinduque, Catanduanes and Polillo. The two subspecies of $P$. manilloe are often considered subspe- 
cies of Tarictic Hornbill P. panini, which is fairly common in forest up to about 1,000 m (Dickinson et al. 1991). In the Sierra Madre we found it at $0-1,350 \mathrm{~m}$, very common or common in all lowland forest areas, and uncommon in the montane forest at Los Dos Cuernos and Mt Cetaceo. The populations of this species and the other hornbill in Luzon, Rufous Hornbill Buceros hydrocorax, are probably declining. Local people in the Sierra Madre, on Mt Pulog and Mt Makiling reported drastic declines in the number of hornbills generally.

Philippine Oriole Oriolus steerii Five subspecies are confined to Luzon, Leyte, Mindanao, Samar, Bohol, Basilan, Bongao, Tawitawi, Masbate and Negros, with a sixth, from Cebu, now considered extinct (Dickinson et al. 1991). The race albiloris, confined to northern Luzon, is sometimes considered a separate species. We found it in the Sierra Madre in the upper storeys of primary forest, selectively logged forest and degraded forest at o-950 $\mathrm{m}$. It was fairly common at Palanan, Dipalayag, Palay, Minuma and Siagot, and uncommon at Diagopanay, Abuan and Los Dos Cuernos. It does not seem to be threatened at present in view of its abundance in the Sierra Madre.

Golden-crowned Babbler Stachyris dennistouni Confined to northern Luzon where it is uncommon in forest and forest edge below 1,000 $\mathrm{m}$ (Dickinson $e t$ al. 1991). Apart from a record from Ilocos Norte province (Dickinson et al. 1991) all records are from the northern Sierra Madre. We found it common at Dimapnat and fairly common in Palanan, Diagopanay, Abuan and Minuma. We also had records from Digollorin and Los Dos Cuernos. Found in primary, selectively logged and degraded forest at $0-1,150 \mathrm{~m}$. This species is still numerous within its very restricted range, but might become threatened as deforestation of the northern Sierra Madre continues.

Grey-backed Tailorbird Orthotomus derbianus Confined to southern and central Luzon and with a separate subspecies at Catanduanes; also known by a single specimen from Palawan (Dickinson et al. 1991). Common in forest, forest edge, and second growth in dense tangles in the understorey (Dickinson et al. 1991). From the Sierra Madre it is reported as far north as the Mt Palanan area (Hornskov 1992), but we did not record it.

Luzon Bush-warbler Cettia seebohmi Known from the Cordillera Central in northern Luzon (the only record from the Sierra Madre being a sighting at Dalton Pass), where common in brush, thickets and the understorey of open forest above $800 \mathrm{~m}$ (Dickinson et al. 1991). It does not seem to be threatened at present (Jensen et al. in prep.).

Ashy-breasted Flycatcher Muscicapa randi Confined to Luzon and Negros. We found it to be rare in the Sierra Madre, only observing one pair, in degraded forest at Los Dos Cuernos (950 m) in April 1991. These birds were $10 \mathrm{~m}$ above the ground in dead branches and feeding on flying insects in flycatcher manner; they were at the same site when we returned five days later, and were seen in the same area in May 1992 (T. H. Fisher verbally). Other records are from Mt Palanan in Isabela province (Hornskov 1992) and Angat Dam (T. H. Fisher 
verbally). If this species is as rare within the rest of its range as it is in the Sierra Madre, it should be considered threatened.

Grey-backed Whistler Pachycephala albiventris Confined to Luzon and Mindoro. Fairly common in forest from lowlands up to 2,000 m (Dickinson et al. 1991). We found it abundant in montane forest and mossy forest at Mt Cetaceo at $1,200-1,600 \mathrm{~m}$, and a single bird was sighted in degraded forest at Siagot at $300 \mathrm{~m}$. The species is probably rare in the lowlands of Luzon; Goodman and Gonzales (1992) report it abundant at Mt Isarog at 1,350 m, but did not locate it below $900 \mathrm{~m}$. It does not seem to be threatened at present.

Mountain Shrike Lanius validirostris Confined to the high mountains of Luzon, Mindoro and Mindanao, above 1,000 $\mathrm{m}$, with different subspecies on each island. Uncommon and local in clearings in oak- and pine-forest, open second growth, forest edge and scrub in grasslands (Dickinson et al. 1991). In Luzon it was previously considered confined to the Cordillera Central (Dickinson et al. 1991). However, we observed the species at Los Dos Cuernos (1,200 m) and Mt Cetaceo $(1,400-1,650 \mathrm{~m})$ in the Sierra Madre. Breeding was recorded at Mt Cetaceo, where one pair was feeding juveniles on 15 May. The species does not seem to be threatened at present.

Flame-crowned Flowerpecker Dicaeum anthonyi Confined to northern Luzon and Mindanao, being uncommon in forests, particularly mossy forest, and forest edge above $800 \mathrm{~m}$ (Dickinson et al. 1991). We recorded a single male only, in montane forest at Dipalayag at 1,050 m. A previous record from the Sierra Madre is from Mt Tabuan at about 1,500 $\mathrm{m}$ (Manuel 1935). The habitat preference and scarcity of this species suggests that it should be regarded as near-threatened.

White-cheeked Bullfinch Pyrrhula leucogenis Confined to the highest mountains of northern Luzon and Mindanao, above $1,250 \mathrm{~m}$, where it is fairly common in mossy forest and forest edge. The species had not previously been recorded from the Sierra Madre. We found it uncommon in the mossy forest of Mt Cetaceo $(1,450-1,650 \mathrm{~m})$, where only 4-7 different birds were sighted. The species might become threatened in the future owing to deforestation.

\section{Conclusions}

The Sierra Madre mountains have the richest avifauna yet known from any forest area in the Philippines. The number of endemic species is extremely high (more than 80 species endemic to the Philippines occur in the Sierra Madre mountains of Isabela province: Danielsen et al. 1993) and the number of threatened species is among the highest in Asia.

About 250 species of bird are known to occur within the northern Sierra Madre mountains. About 200 of these are believed to breed in the area and about 120 can probably only survive in forested areas (Danielsen et al. 1993). In 
comparison, 135 species are known from Mt Isarog (Goodman and Gonzales 1990) and 133 from Mt Katanglad, Mindanao (Heaney and Peterson 1992). These two smaller areas had previously been judged to hold the richest Philippine avifaunas hitherto documented (Heaney and Peterson 1992).

The deep valley near $15^{\circ} 30^{\prime} \mathrm{N}$ that separates the northern and the southern Sierra Madre mountains apparently acts as strong biogeographical barrier. Stachyris dennistouni is replaced by Black-crowned Babbler S. nigrocapitata south of the valley (Dickinson et al. 1991), and Ptilinopus merrilli, Phaenicophaeus superciliosus and Napothera rabori are represented by different subspecies either side of this divide.

The northern Sierra Madre mountains are one of the most important areas for conservation of threatened bird species in Asia. Given the diversity and uniqueness of the avifauna it is surprising that its priority for conservation is only now starting to be recognized.

Almost all threatened and near-threatened species of bird are found in the foothill forest at approximately $500 \mathrm{~m}$, but many are found at higher densities either below or above this altitude. Conservation of forest at all altitudes is therefore important, particularly while it remains unclear whether some altitudinal migration may occur, at least in some species, thus requiring the preservation of adjacent, representative tracts of habitat at all levels. Some species can be properly protected only if areas with lowland forest are conserved: Prioniturus luconensis, Centropus unirufus, Ceyx melanurus, Oriolus isabellae, Napothera rabori, Hypothymis coelestis, $H$. helenae, Terpsiphone cinnamomeus. Others depend on the protection of forest at higher altitudes: Ptilinopus marchei, Otus longicornis, Pitta kochi, Stachyris whiteheadi, Bradypterus caudatus, Rhinomyias insignis. The latter group of species are already protected within the Mt Pulog National Park in the Cordillera Central, but their populations there are small and apparently decreasing compared with those in the Sierra Madre (Jensen et al. in prep.).

The Philippine government is now embarking on a large programme to develop a comprehensive system of protected areas in the country (IPAS: Integrated Protected Area System). Since existing protected areas in the region are inadequate for the necessary conservation of habitats, the extension of IPAS to embrace the northern Sierra Madre, including the Palanan Wilderness Area, is of paramount importance. At present the Palanan Wilderness Area does not cover forest at the highest altitudes, and it must be recommended that the montane forests of Los Dos Cuernos and Mt Cetaceo north of the wilderness area be included within the protected area. The full implementation of the nationwide logging ban in primary forests, forests above 1,000 $\mathrm{m}$ and on steep slopes is vital in the Sierra Madre mountains.

Presumably second growth and selectively logged forest can support many of the important species as long as healthy populations survive in nearby primary forest, but selectively logged forests are unfortunately very susceptible to serious forest fires (Lambert 1992b). We were unable to locate several lowland species at the lowest altitudes where only a few remnants of primary forest are left, suggesting that these latter areas are too small to secure the long-term survival of the more sensitive species. The scarcity of lowland species near sea 
level seems to be a direct effect of the massive habitat destruction throughout the region.

The forests of the Sierra Madre can probably support viable populations of all bird species at present, even those that naturally occur at low densities and which will probably become extinct in other smaller isolated forest areas.

To secure the survival of sufficiently large populations of species with low densities, notably Pithecophaga jefferyi and Spizaetus philippinensis, it is important that the total forested area remain stable. Forest used for selective logging in a sustainable manner will ensure the survival of the threatened species far better than if these areas are entirely denuded, but some species may disappear if larger areas of primary forest are not left nearby. In addition, the development of sustainable community-based forestry programmes in the logged-over forests is recommended as a means of securing the largest possible closed-canopy area of forest.

The ultrabasic forest is of limited importance for threatened species of bird. However, both Napothera rabori and Cyornis herioti were found in this forest type, and Hypothymis helenae was found in higher densities there than anywhere else. The ultrabasic forests in the Sierra Madre are considered to be very important to the conservation of plants (C. Ridsdale in litt.). Areas with ultrabasic forest should therefore be added to the Palanan Wilderness Area.

\section{Acknowledgements}

The joint surveys of DENR (Department of Environment and Natural Resources, Philippines) and ICBP (International Council for Bird Preservation) in 1991 and 1992 were generously funded by Aage V. Jensens Charity Foundations. Participants in the fieldwork were: (both years) R. Catabui, A. Diesmos, M. Heegaard, A. Mallari; (1991 only) R. Altamirano, R. Baguisi, F. Danielsen, O. Jakobsen, A. Jensen, M. K. Poulsen and K. S. Schoyen; and (1992 only) D. S. Balete, T. D. Christensen, V. Cruz, T. Lund, A. S. Manamtam, H. Mouritsen, G. Pallaya and G. Reyes. Thanks go to T. D. Christensen, F. Danielsen, M. Heegaard, T. Lund, O. Jakobsen, A. Jensen and F. R. Lambert for helpful comments on drafts of this manuscript. T. H. Fisher very kindly made all his notes and records available. Further acknowledgements in this project are to be found in Danielsen et al. (1993).

\section{References}

Alonzo-Pasicolan, S. (1992) The bird catchers of Dalton Pass. Bull. Oriental Bird Club 15: 33-36.

Amadon, D. and duPont, J. E. (1970) Notes on Philippine birds. Nemouria 1: 1-14.

Andersen, C. Y., Poulsen, M. K., Jacobsen, O. F. and Heegaard, M. (1992) Observations on the Luzon Water Redstart Rhyacornis bicolor in the Mount Pulog National Park, Philippines. Forktail 7: 147-150.

Baud, F. J. (1978) Oiseaux des Philippines de la collection W. Parsons. II. Luzon, Mindoro et Palawan. Revue Suisse Zool. 85: 55-97.

Collar, N. J. and Andrew, P. (1988) Birds to watch: the ICBP world checklist of threatened birds. Cambridge, U.K.: International Council for Bird Preservation (Techn. Publ. 8). 
Collar, N. J., Crosby, M. J. and Stattersfield, A. J. (1994) Birds to watch 2: the world list of threatened birds. Cambridge, U.K.: BirdLife International (BirdLife Conservation Series 4).

Danielsen, F., Jensen, A., Miranda, H. and Caleda, M. (1992) A preliminary survey of the Philippine Eagle Pithecophaga jefferyi and the conservation of the northern Sierra Madre mountains in the Philippines. Manila: DENR and ICBP.

Danielsen, F., Balete, D. S., Christensen, T. D., Heegaard, M., Jacobsen, O. F., Jensen, A., Lund, T. and Poulsen, M. K. (1993) Conservation of biological diversity in the Sierra Madre Mountains of Isabela and southern Cagayan province, the Philippines. Manila: DENRICBP, and Copenhagen: DOF.

Delacour, J and Mayr, E. (1946) Birds of the Philippines. New York: Macmillan.

DENR (1987) Forest resources of Region 2. Manila: Philippine-German Forest Resources Inventory Project, Bureau of Forest Development, DENR.

Dickinson, E. C., Kennedy, R. S. and Parkes, K. C. (1991) The birds of the Philippines. Tring, U.K.: British Ornithologists' Union (Check-list 12).

Dickinson, E. C. (1989) A review of larger Philippine swiftlets of the genus Collocalia. Forktail 4: 19-53.

De Roever, J. (1990) Notes on the Luzon Wren-Babbler. Bull. Oriental Bird Club 12: 33-34.

DuPont, J. E. (1971) Notes on Philippine birds (No.1). Nemouria 3: 1-6.

Dutson, G. (1993) A sighting of Ficedula (crypta) disposita in Luzon, Philippines. Forktail 8: $144-147$.

Evans, T. D., Dutson, G. C. L. and Brooks, T. M. (1993) Cambridge Philippines Rainforest Project 1991. Cambridge, U.K.: BirdLife International (Study Report no.54).

Gibbs, D. (1984) The Philippines, 22 January-2 March 1984. Unpublished report.

Gilliard, E. T. (1950) Notes on a collection of birds from Bataan, Luzon, Philippine Islands. Bull. Amer. Mus. Nat. Hist. 94: 457-504.

Gonzales, P. C. and Rees, C. P. (1988) Birds of the Philippines. Manila: Haribon.

Gonzales, P. C. and Kennedy, R. S. (1990) A new species of Stachyris babbler (Aves: Timaliidae) from the island of Panay, Philippines. Wilson Bull. 102: 367-379.

Goodman, S. M. and Gonzales, P. C. (1990) The birds of Mt Isarog National Park, southern Luzon, Philippines with particular reference to altitudinal distribution. Fieldiana 6o: 1-39.

Greensmith, A. (1990) The Philippines, 4 March-9 April 1990. Unpublished report.

Gretton, A (1990) Recent records. Bull. Oriental Bird Club 11: 40-48.

Heaney, L. R. and Peterson, A. T. (1992) Inventory of the vertebrates of Mt Katanglad Nature Park. Chicago: Field Museum of Natural History.

Hornskov, J. (1992) The Philippines, 1987. Unpublished report.

ICBP (1992) Putting biodiversity on the map. Cambridge, U.K.: International Council for Bird Preservation.

IUCN (1991) The conservation atlas of tropical forests: Asia and the Pacific. London and Basingstoke: Macmillan Press.

Jensen, A., Poulsen, M. K., Accos, J., Jakobsen, O. F. and Andersen, C. Y. (in prep.). Conservation of biological diversity of Mount Pulog National Park, the Philippines. Manila: DENR, and Cambridge: BirdLife International.

Kennedy, R. S. (1977) Notes on the biology and population status of the Monkey-eating Eagle of the Philippines. Wilson Bull. 89: 1-20.

Kennedy, R. S. (1979) Conservation research of the Philippine Eagle. National Geographic Soc. Res. Rep. 18: 401-414.

Lambert, F. R. (1992a) The status of the Philippine Cockatoo Cacatua haematuropygia in Palawan and the Sulu Islands, Philippines. Unpublished.

Lambert, F. R. (1992b) The consequences of selective logging for Bornean lowland forest birds. Phil. Trans. R. Soc. Lond. 335: 443-457. 
Lewis, R. E. (1986) A rain-forest raptor in danger. Oryx 20: 170-175.

Manuel, C. G. (1935) New birds from northern Luzon, Philippine Islands. Philippine J. Sci. 56: 93-95.

Manuel, C. G. (1936a) New Philippine fruit pigeons. Philippine J. Sci. 59: 307-309.

Manuel, C. G. (1936b) A review of Philippine pigeons, II: Subfamily Ptilinopodinae. Philippine J. Sci. 59: 327-336.

Maus, J. and Schieferli, E. (1989) Environmental problems in north-east Luzon. Leiden: Centre for Environmental Studies, Leiden University (Students' Report 12).

McClure, H. E. (1974) Migration and survival of the birds of Asia. Bangkok: U.S. Army Medical component, SEATO Medical Project.

McClure, H. E. and Leelavit, P. (1972) Birds banded in Asia during the MAPS Program, by locality, from 1963 through 1971. San Francisco: U.S. Army Research and Development Group, Far East Report No. FE-315-7.

McGregor, R. C. (1903) On birds from Luzon, Mindoro, Masbate, Ticao, Cuyo, Culion, Cagayan Sulu, and Palawan. Bull. Philippines Mus. 1: 3-12.

McGregor, R. C. (1909-1910) A manual of Philippine birds. Manila: Bureau of Science.

McGregor, R. C. (1910) Birds from Pauai and Mount Pulog, subprovince of Benguet, Luzon. Philippine J. Sci. 5: 135-138.

McGregor, R. C. and Manuel, C. G. (1936) Birds new and rare in the Philippines. Philippine J. Sci. 59: 317-326.

Morioka, H. and Sakane, T. (1979) Breeding avifaunas of Mt Puguis, northern Luzon and Baracatan, Mindanao, Philippines (Part 1). Bull. Nat. Sci. Mus. (Japan), Ser. A (Zool.) 5(1): 65-74.

Myers, N. (1988) The primary source: tropical forests and our future. New York: W. W. Norton and Company.

Ogilvie Grant, W. R. (1895a) On the birds of the Philippine Islands. Part III. The mountains of the province of Isabella, in the extreme north-east of Luzon. Ibis (7)1: 106-117.

Ogilvie Grant, W. R. (1895b) New species of birds discovered by Whitehead in the mountains of Lepanto, in northern Luzon. Ibis (7)1: 484-486.

Ogilvie Grant, W. R. (1895c) On the birds of the Philippine Islands. Part IV. The province of Albay, south-east Luzon, and the adjacent island of Catanduanes. Ibis (7)1: 249267.

Ogilvie Grant, W. R. (1896) On the birds of the Philippine Islands. Part VI. The vicinity of Cape Engaño, N. E. Luzon, Manila Bay, and Fuga Island, Babuyan Group. Ibis (7)2: 101-128.

Ogilvie Grant, W. R. and Whitehead, J. (1898) On the nests and eggs of some rare Philippine birds. Ibis (7)4: 231-247.

Parkes, K. C. (1970) A revision of the Philippine Trogon (Harpactes ardens). Nat. Hist. Bull. Siam Soc. 23: 345-352.

Parkes, K. C. (1971) Taxonomic and distributional notes on Philippine birds. Nemouria 4: $1-67$.

Rabor, D. S. (1977) Philippine birds and mammals. Quezon City: U.P. Science Education Centre.

Rand, A. L. (1970). Species formation in the blue monarch flycatcher genus Hypothymis. Nat. Hist. Bull. Siam Soc. 23: 353-365.

Rand, A. L. and Rabor, D. S. (1967) New birds from Luzon, Philippine Islands. Fieldiana Zool. 51(6): 85-89.

Ripley, D. and Marshall, J. T. (1967) A new subspecies of flycatcher from Luzon, Philippine Islands (Aves; Muscicapinae). Proc. Biol. Soc. Washington 80: 243-244.

Stattersfield, A. J., Crosby, M. J., Long, A. J. and Wege, D. C. (in prep.) Global directory of endemic bird areas. Cambridge, U.K.: BirdLife International (BirdLife Conservation Series). 
Turton, J. M., Speight, G. J. and Rowland, R. (1986) Philippines, 31 January-28 March 1986. Unpublished report.

Walters, J. S. (I991) Marine survey report, Palanan Wilderness Area Biodiversity Survey. Manila: Conservation International.

Whitehead, J. (1899) Field-notes on birds collected in the Philippine Islands in 1893-6. Ibis (7)5: 81-111, 210-246, 381-399, 485-501.

Whitmore, T. C. (1984) Tropical rain forests of the Far East. Oxford: Clarendon Press.

\section{K. POULSEN}

Dansk Ornitologisk Forening, Vesterbrogade 140, DK-1620 Copenhagen V, Denmark. Current address: BirdLife International Maluku Field Office, P.O. Box 1097, Ambon 97000, Maluku, Indonesia. 